\section{Los orígenes de la reflexión teológica de Zubiri*}

\author{
Antonio GonZÁLEZ**
}

RECIBO: 19-09-13 - APROBACIÓN: 16-06-14

Resumen: El objeto de estas líneas es intentar esclarecer los orígenes de las posiciones teológicas que Zubiri llegó a hacer propias en su obra más madura. Por ello, nos dirigiremos fundamentalmente a dos textos de Zubiri: "Helenismo y cristianismo" y "El ser sobrenatural: Dios y la deificación en la teología paulina”. Dichos textos permiten dar cuenta de sus primeros pasos en el campo de la teología, y resultan valiosos para la comprensión de su pensamiento teológico definitivo, en relación con los conceptos claves de su metafísica.

Palabras Clave: Zubiri, teología paulina, deificación, teología filosófica.

PARA CITAR ESTE ARTÍCULO:

González, Antonio. "Los origenes de la reflexión teológica de Zubiri." Theologica Xaveriana 179 (2015): 209-250. http://dx.doi.org/10.11144/javeriana.tx65-179.ortz
The Origins of Zubiri's Theological Reflection

Aвsтract: The purpose of these lines is to try to clarify the origins of the theological positions that Zubiri took on the mature stage of his work. For this reason, we will refer mainly to two of his writings: "Hellenism and Christianism" and "The Supernatural Being: God and the deification in Pauline Theology". They both provide and account of Zubiri's first steps in the field of Theology, and are valuable for the understanding of his definite theological thought, in relation to the key concepts of his metaphysics.

Key words: Zubiri, Pauline Perspective, deification, philosophical theology.

\section{As origens da reflexão teológica de Zubiri}

Resumo: O objetivo destas linhas é tentar esclarecer as origens das posiçóes teológicas que Zubiri chegou a tornar próprias em sua obra mais madura. Por isso, nos dirigiremos fundamentalmente a dois textos de Zubiri: "Helenismo y cristianismo" e "El ser sobrenatural: Dios y la deificación en la teología paulina". Tais textos permitem dar conta de seus primeiros passos no campo da teologia, e são valiosos para a compreensão de seu pensamento teológico definitivo, em relação com os conceitos-chave de sua metafísica.

Palavras-chave: Zubiri, teologia paulina, deificação, teologia filosófica.

\footnotetext{
*Artículo e reflexión elaborado a partir de la participación en el III Congreso Internacional Xavier Zubiri, que tuvo lugar en el Salón de Honor de la Pontificia Universidad Católica de Valparaíso, Chile, en 2010.

** Doctor en Filosofía, Universidad Pontificia Comillas, Madrid; Doctor en Teología, Philosophisch-Theologische Hochschule Sankt Georgen, Frankfurt. Profesor y conferenciante en universidades de España, Alemania, América Latina y Estados Unidos; director de Estudios y Publicaciones de la Fundación Xavier Zubiri.
} 


\section{Introducción}

Los orígenes de la reflexión teológica de Zubiri ya han sido objeto de algunas investigaciones históricas. Pienso, en concreto, en la tesis de licenciatura de Emilio José Justo Domínguez ${ }^{1}$ y en los trabajos de Guillermina Díaz Muñoz. ${ }^{2}$ Estas investigaciones tienen indudablemente un alto valor histórico, en cuanto que nos muestran algunas de las fuentes teológicas a las que Zubiri recurrió en sus años de formación. Sin embargo, creo necesario preguntarse si con ellas se explica suficientemente el origen de las posiciones teológicas de Zubiri.

En este trabajo nos cuestionaremos, en concreto, por otros posibles influjos teológicos recibidos por Zubiri y, además, tendremos también en cuenta el contexto filosófico de esas influencias. Nuestra tesis es que las influencias teológicas asumidas por Zubiri son más ricas y variadas que las detectadas hasta ahora, y que esas influencias tienen que situarse en un contexto filosófico para ser comprendidas cabalmente.

\section{Las teologías de "Helenismo y cristianismo"3}

Una primera aproximación a los dos textos ya mencionados de Zubiri nos muestra un vivo interés de Zubiri por la teología del apóstol Pablo. Si el texto conservado en Naturaleza, historia, Dios ${ }^{4}$ se refiere a Pablo en su mismo título, una buena parte del curso "Helenismo y cristianismo" se ocupa en la interpretación de la Carta a los Efesios, tratada como una carta auténtica de Pablo. Se trata de un interés comprensible, dada la relevancia de la teología paulina para entender los orígenes del cristianismo. Con frecuencia, la interpretación de Pablo determina la propia interpretación del cristianismo, y Zubiri, como veremos, no hace una excepción a esto.

\footnotetext{
${ }^{1}$ Ver a Domínguez, "La deificación en el pensamiento de Xavier Zubiri” (2002). El autor analizó los posibles mediadores en el interés de Zubiri por la teología griega, atendiendo especialmente al papel desempeñado por el Instituto San Sergio de París, en el que encontraron refugio teólogos orientales exiliados, y a las influencias de autores occidentales mencionados expresamente por Zubiri, como Anselm Stolz y Michael Schmaus.

${ }^{2}$ En especial, puede verse su libro sobre Teología del misterio en Zubiri (2008). El trabajo se centró en la posible influencia sobre Zubiri de la llamada "teología de los misterios", representada por autores como Odo Casel y Viktor Warnach

${ }^{3} \mathrm{He}$ utilizado un borrador cedido gentilmente por Manuel Mazón, editor de los Cursos universitarios de Zubiri. En concreto, el curso "Helenismo y cristianismo" habrá de aparecer en el Volumen IV de dichos Cursos.

${ }^{4}$ Ver "El ser sobrenatural: Dios y la deificación en la teología paulina", en Naturaleza, historia, Dios, 455-542. Al comienzo de este texto, Zubiri advierte que su origen está en el mencionado curso "Helenismo y cristianismo", así como en unas reuniones que dirigió en París en los años 1937-1939.
} 
Una influencia permanente en la obra de Zubiri es la de Friedrich Schleiermacher (1768-1834), a quien aquél se refiere repetidamente en su curso "Helenismo y cristianismo". En cierto modo, se puede decir que con Schleiermacher el paradigma teológico moderno, iniciado con la Reforma, llega a su plena madurez. ${ }^{5} \mathrm{Al}$ mismo tiempo, también puede considerarse que Schleiermacher es el iniciador de nuevas líneas de pensamiento que han sido decisivas para la teología contemporánea. ${ }^{6}$

Zubiri, como otros muchos, valora el hecho de que Schleiermacher supo situar a Pablo, y con ello, los orígenes del cristianismo, en la perspectiva de una idea de la religión. Como es sabido, para Schleiermacher, la religión consiste en un "sentimiento de dependencia absoluta" de Dios, que llegaría a su culminación en Jesús. ${ }^{7}$ Para Schleiermacher, Pablo se encuentra en perfecta continuidad con Jesús, lo que se expresa en su concepción del cristianismo como una elevación de la existencia humana determinada por ese sentimiento de dependencia absoluta.

Por eso, la posición de Pablo queda para Schleiermacher reflejada en una cita que no proviene de las epístolas paulinas, sino del libro de Hechos, y constituye además una cita de Epiménides de Creta: es la famosa expresión "en él vivimos, nos movemos y somos" (Hch 17,28).

También esta cita será una de las favoritas de Zubiri, y también ella refleja, como veremos, el sentido fundamental su interpretación de Pablo, por más que esa interpretación no sea la misma que la de Schleiermacher. De Schleiermacher Zubiri valora altamente el hecho de que supo hacer de la teología una hermenéutica de la existencia humana, algo que nos dice mucho sobre la influencia de Heidegger sobre esta etapa del pensamiento de Zubiri. Sin embargo, frente a Schleiermacher, Zubiri duda que la religión sea un mero asunto de sentimiento.

Mientras que la contraposición entre razón y sentimiento es propia de la modernidad, y sigue afectando a autores contemporáneos como Rudolf Otto, Zubiri recibirá también de Heidegger la denuncia de esa contraposición. Para Zubiri, lo religioso se sitúa en una dimensión que afecta a la realidad entera del hombre, y no solo a una de sus facultades.

Por otra parte, Zubiri entiende que Schleiermacher tendría que haber explicado en qué consiste esa elevación de la existencia humana que caracteriza al cristianismo desde sus orígenes. Y esto nos muestra algo decisivo para entender la posición teológica

\footnotetext{
${ }^{5}$ Küng, Grandes pensadores cristianos, 157.

${ }^{6}$ Barth, Protestant Thought: From Rousseau to Ritschl, 306.

${ }^{7}$ Schleiermacher, Der christliche Glaube, 2. Aufgabe (1830-1831), Vol. 2. (En Kritische Gesamtausgabe, Vol. 13, 41-60, por F. Schleiermacher. Berlin-New York: Walter de Gruyter, 2003).
} 
de Zubiri, que es precisamente el interés ontológico que conduce, como veremos, a su lectura del cristianismo en términos de deificación o "deiformación". ${ }^{8}$

Otra línea de pensamiento teológico de la que Zubiri se hace eco es la llamada "Escuela de Tubinga", altamente influida por el pensamiento hegeliano. Zubiri se refiere expresamente a Ferdinand Christian Baur (1792-1860), quien llevó a cabo una interpretación dialéctica de los orígenes del cristianismo. De una manera muy propia del pensamiento germano de ese tiempo, Baur contraponía el judaísmo al cristianismo, que representaría un principio autónomo, esencialmente distinto del judío, y caracterizado por la participación, por la fe, del espíritu finito en el Espíritu Absoluto. ${ }^{9}$ De este modo, el cristianismo afirmaría lo espiritual del ser humano frente a la tendencia judía a atender a lo meramente material y corporal. El apóstol Pablo sería el representante de este principio autónomo, al que se le opondría la tendencia petrina, que trataría de afirmar, dentro del universalismo cristiano, lo particular del judaísmo.

Zubiri consideró la obra de Baur como lo más sólido de la teología especulativa del siglo XIX, pero al mismo tiempo ya señalaba que los esquemas especulativos no son aplicables a la historia, y que el Espíritu del que habla Pablo tiene poco que ver con el Espíritu de la filosofía hegeliana. Además, Zubiri ya sabía que la distinción paulina entre carne y espíritu no tiene nada que ver con la contraposición entre cuerpo y alma. Zubiri, al mostrar de nuevo la influencia del pensamiento de Heidegger, señalará que la carne y el espíritu se refieren al ser humano completo, considerado, eso sí, según dos "principios de existencia". ${ }^{10}$ Finalmente, Zubiri indicaba en su curso que Baur no habia explicado la relación entre Jesús mismo y los orígenes del cristianismo.

Precisamente este interés por Jesús es algo que caracterizó buena parte de la teología liberal protestante y del modernismo católico. Entre los liberales protestantes Zubiri cita sobre todo a Adolf von Harnack (1851-1930), mientras que entre los modernistas Zubiri se refiere especialmente a Alfred Loisy (1857-1940). Ambos son autores que Zubiri conoció bien. ${ }^{11}$

\footnotetext{
${ }^{8}$ El término "deificación" aparece en el texto de 1944, mientras que en los textos de madurez se introduce el término "deiformación" para indicar que, si bien la deificación" concierne solamente al justo, la deiformación atañe a todo ser humano. Ver a Zubiri, El problema teologal del hombre: cristianismo, 37.

${ }^{9}$ Baur, Paulus. Der Apostel Jesu Christi, 3.

${ }^{10}$ Propia de la influencia de Heidegger es la alusión a "modos de existencia". Sin embargo, la distinción misma entre carne y espíritu parece deberse, no a Heidegger, sino al conocimiento exegético de Zubiri.

${ }^{11}$ Zubiri tenía en su biblioteca personal varios libros de Harnack, entre otros, su Dogmengeschichte (Leipzig, 1922). También adquirió varias obras de Loisy, como L'évangile et l'église (Paris, 1908).
} 
Sus biógrafos han llamado la atención sobre la honda influencia que el modernismo tuvo sobre las crisis religiosas del joven Zubiri. ${ }^{12} \mathrm{~A}$ la altura del curso "Helenismo y cristianismo", el modernismo se puede considerar como una influencia pasada. Sin embargo, en ese curso Zubiri todavía valora el hecho de que la hermenéutica liberal y modernista pusiera los orígenes del cristianismo en Jesús mismo, y no en Pablo; pero para Zubiri el problema consiste en que con ello no se aclara cómo es posible la transición entre uno y otro.

Según Zubiri, de la misma manera que Baur nos presentaba un cristianismo sin Jesús, los liberales y modernistas tienden a presentar un Jesús sin cristianismo. Jesús aparece caracterizado como un mero maestro de moral, y se hace difícil entender cómo es posible que a partir de él se constituyera el cristianismo como religión de salvación. En cierto modo, puede decirse que el liberalismo teológico instituyó una contraposición entre Jesús y Pablo que ha pasado a la cultura popular, pero que para el Zubiri de estos años ya es perfectamente insuficiente. Para él, era necesario explicar cuáles fueron las razones del paso de uno a otro.

La temprana influencia del modernismo sobre Zubiri, con su concepción de la revelación como proceso puramente inmanente de descubrimiento de verdades religiosas, invalida las explicaciones de la obra teológica de Zubiri que presuponen un estadio tempranamente "dogmático" o "escolástico", que se habría ido abriendo paulatinamente a concepciones más racionalistas, como resultado del Concilio Vaticano II.

Esto no son más que proyecciones sobre Zubiri de un proceso por el que sin duda pasaron muchos católicos españoles, pero que es distinto de la evolución religiosa y teológica de Zubiri. En su caso, lo que tenemos es más bien una transición desde posiciones modernistas muy tempranas, en las que se prescindía de cualquier posibilidad de una revelación particular de Dios, hacia el esbozo de una concepción más integral de la revelación. En ella habrá lugar tanto para la marcha históricamente situada de la razón humana que se apropia de posibilidades de entender lo divino como también para lo que Zubiri consideraba como iniciativas de Dios. ${ }^{13}$

La alternativa típica entre el inmanentismo y el extrincesismo proviene, en el fondo, de una metafísica dualista y una epistemología racionalista, propias de la modernidad, que Zubiri comenzó a abandonar a partir de su contacto con la filosofía contemporánea. Precisamente su posterior concepción de cristianismo en términos de "deiformación" tiende a evitar ciertos dualismos propios de la filosofía del siglo XIX.

\footnotetext{
${ }^{12}$ Corominas y Vicens, Xavier Zubiri. La soledad sonora, 71-72; 88-91; 101-106; 136-139.

${ }^{13}$ Zubiri, El problema teologal del hombre: cristianismo, 67-68.
} 
En cualquier caso, a la altura del curso "Helenismo y cristianismo", Zubiri disponía ya de un horizonte filosófico más amplio que el presupuesto por el modernismo.

En el campo teológico y exegético, el optimismo liberal del siglo XIX fue abruptamente puesto en entredicho por la llamada "escuela escatológica", de la que Zubiri también se hace eco en su curso "Helenismo y cristianismo". Johannes Weiss (1863-1914) señaló que el anuncio del reinado de Dios por parte de Jesús, lejos de poder ser interpretado como un simple compendio de todos los ideales liberales de igualdad y fraternidad, lo que verdaderamente implicaba era el final del mundo. ${ }^{14}$ Con esto, Jesús aparece como un judío del siglo I, absolutamente ajeno a los ideales de la modernidad.

En cambio, la escuela escatológica pudo establecer puentes entre Jesús y Pablo, pues la expectativa escatológica de Jesús respecto al final de los tiempos tendría una cierta continuidad en la esperanza paulina en el pronto regreso del Mesías. Zubiri, en el curso "Helenismo y cristianismo", valora sin duda el que la escuela escatológica haya podido establecer esta continuidad. Sin embargo, Zubiri mantiene, respecto a Weiss, muchas de las críticas formuladas respecto a Loisy, a quien considera en buena medida influido por el primero.

Desde el punto de vista de Zubiri, entre el Jesús de la escuela escatológica y la teología de Pablo seguiría habiendo una cesura fundamental, que quedaría sin explicar. Por más que Jesús y Pablo hayan mostrado intereses escatológicos, la teología tendría que explicar por qué en Pablo se llega a proclamar la divinidad de Jesús. En este aspecto, Zubiri llega a sugerir que hubiera sido necesario entender a Jesús desde Pablo, para así poder entender la evolución que lleva de uno a otro.

Una explicación sobre la proclamación paulina de la divinidad de Jesús fue la que trató de dar la llamada "escuela de la historia de las religiones" (Religionsgeschichtliche Schule). Esta escuela trató de entender los orígenes del cristianismo a partir de un estudio comparativo con las llamadas "religiones de misterios" (más bien habría que decir "cultos mistéricos") que pululaban por el imperio romano. En estos cultos encontramos dioses que mueren y resucitan períodicamente, siendo el culto una manera de incorporarse a la suerte propia de la divinidad. Desde esta perspectiva, ciertos elementos centrales del culto cristiano primitivo, como el bautismo y la santa cena, fueron interpretados como préstamos tomados de los cultos mistéricos.

\footnotetext{
${ }^{14}$ Ver a Weiss, Die Predigt Jesu vom Reiche Gottes (1892). Por supuesto, en la actualidad ya no se piensa que la apocalíptica judía hablara de un final del mundo espacio-temporal, sino más bien de una transformación histórica radical, después de la cual el mundo no dejaría de existir.
} 
Así, por ejemplo, la interpretación paulina del bautismo como incorporación a la muerte y resurrección de Jesús pudo ser entendida como un eco de las iniciaciones mistéricas, y la santa cena fue entendida como un ritual influenciado por los cultos dionisíacos en los que se devoraba simbólicamente la carne del dios. Más adelante, algunos autores, como Richard August Reitzenstein (1861-1931), entendieron que el enfoque desde las religiones de misterios era insuficiente, e introdujeron en las escuelas de la historia de las religiones el interés por el influjo de otras corrientes, especialmente del gnosticismo, sobre el cristianismo primitivo.

El cristianismo primitivo no solo habría tomado del gnosticismo muchos de sus términos ("psíquico", "espiritual” o "pneumático", "gnosis", "carisma”, etc.) sino sobre todo el mito del "redentor redimido", es decir, de un salvador bajado del cielo que es él mismo liberado de los lazos de la muerte, y nos muestra el camino de regreso a la divinidad. ${ }^{15}$

En la actualidad, las tesis de la escuela de la historia de las religiones se suelen considerar en su conjunto como superadas. Por una parte, nuestro conocimiento de los cultos mistéricos sigue siendo muy limitado (los participantes en ellos fueron bastante exitosos en mantener su carácter secreto), y para los ritos cristianos del bautismo y de la santa cena resulta mucho más fácil encontrar antecedentes claros en el judaísmo en general, y en la práctica de Jesús y sus discípulos en particular.

Respecto del gnosticismo, el problema consiste en que el mito del "redentor redimido" no está atestiguado antes del siglo II, y refleja claramente influjos judíos y cristianos. En general, la investigación actual sobre los orígenes del cristianismo insiste mucho más en el carácter judío del mismo. Zubiri, en su curso "Helenismo y cristianismo", ya consideraba la hipótesis de un influjo directo y masivo de los cultos mistéricos sobre el cristianismo primitivo como una teoría decimonónica superada.

En esto puede haber sido determinante para Zubiri no solo la aportación de Johannes Weiss, quien subrayó los orígenes judíos del cristianismo, sino también la obra del P. Lagrange. ${ }^{16}$ Igualmente, Zubiri señalaba en su curso que la utilización de términos o ideas gnósticas en los textos cristianos primitivos no significa que tales textos

\footnotetext{
${ }^{15}$ Zubiri tenía en su biblioteca personal varias de las obras de Reitzenstein, entre ellas, su Poimandres. Studien zur griechisch-ägyptischen und frühcristlichen Literatur (Leipzig, 1904).

${ }^{16}$ Ver a Lagrange, Le sens du christianisme d'après l'exégèse allemande (1918). En el texto, que Zubiri tenía en su biblioteca personal, Lagrange criticaba la exégesis protestante desde Lutero hasta su tiempo, incluyendo la escuela escatológica, y tenía también un capítulo dedicado a crítica de la escuela de la historia de las religiones (269-305). El aprecio de Zubiri por la obra del padre Lagrange se muestra en su artículo necrológico de 1938 titulado "En memoria del P. Lagrange O.P., doctor de la tradición bíblica", publicado en Sobre el problema de la filosofía y otros escritos (1932-1944), 285 y ss.
} 
fueran gnósticos, sino más bien que en ellos se toma posición frente al gnosticismo.

No obstante, hay algo que Zubiri valora enormemente de la escuela de la historia de las religiones, y especialmente en Wilhelm Bossuet (1865-1920), que es un autor que Zubiri cita repetidamente. Según Zubiri, la escuela de la historia de las religiones acertó en considerar al cristianismo en términos de religión y no en términos puramente éticos. ${ }^{17}$

Es algo que sin duda resulta determinante para los trabajos posteriores de Zubiri, en los que el cristianismo será considerado siempre en el marco de la religación. Según Zubiri, esta aproximación al cristianismo en términos religiosos ha capacitado a la escuela de la historia de las religiones para valorar la importancia del culto y, por tanto, de lo colectivo, frente a las tendencias más individualistas de la teología liberal.

Sin embargo, Zubiri entiende que los aspectos externos, vitales y religiosos del culto no logran dar cuenta de aquello que resulta verdaderamente decisivo para comprender la teología paulina. Y para hacernos con esa clave tenemos que dar un paso más y referirnos a un autor que no es precisamente un teólogo.

\section{Heidegger como lector de Pablo}

En el semestre de invierno de 1920-1921, Heidegger impartió un curso sobre "Introducción a la fenomenología de la religión”, seguido, en el semestre de verano, sobre un curso sobre "Agustín y el neoplatonismo" ${ }^{18}$ Este segundo curso fue sin duda conocido por Zubiri, quien lo utilizó en sus propias explicaciones del pensamiento de Agustín. ${ }^{19}$ El primer curso, en cambio, se trasmitió solamente a través de los apuntes de algunos asistentes, pero Zubiri tuvo acceso al mismo, tal como se puede comprobar por la copia existente en su archivo personal. ${ }^{20}$

El planteamiento de Heidegger, en su "Introducción a la fenomenología de la religión”, muestra una concepción muy propia de esa disciplina. En esos años,

\footnotetext{
${ }^{17}$ Puede verse, por ejemplo, Bossuet, Das Wesen Der Religion Dargestellt an Ihrer Geschichte (1920). Otro libro influyente de Bossuet fue su Kyrios Christos. Geschichte des Christus-Glauben von den Anfängen des Christentums bis Irenäus (1913).

${ }^{18}$ Estos cursos han sido publicados en el volumen 60 de la Gesamtausgabe. Ver a Heidegger, Phänomenologie des religiösen Lebens (1995).

${ }^{19}$ Así, por ejemplo, Zubiri comienza su curso sobre Agustín pasando revista a los libros de E. Troeltsch, A. Von Harnack, y W. Dilthey, igual que había hecho Heidegger en su curso (Zubiri, Cursos universitarios, Vol. 2, 27ss.). Por supuesto, esto no significa que Zubiri comparta la interpretación heideggeriana de Agustín.

${ }^{20}$ Con la signatura 13.1, que indica "Handschrift von Prof. Oskar Becker".
} 
Heidegger ya sostiene que el objeto de la fenomenología no es otro que la experiencia fáctica de la vida. Ahora bien, esta experiencia fáctica incluye la experiencia religiosa. Frente a los trabajos de Rudolf Otto, Heidegger entiende que lo religioso afecta a la existencia entera, y no puede ser simplemente confinada en el ámbito de lo sentimental o de lo irracional.

En cualquier caso, Heidegger quiere estudiar la experiencia religiosa de un modo fenomenológico, a partir de experiencias religiosas concretas. Esta es la razón por la que, en el semestre de invierno de 1920-1921 se ocupó especialmente con el pensamiento de Pablo, mientras que el siguiente semestre estuvo dedicado a la figura de Agustín. $\mathrm{Su}$ objetivo no fue una lectura exegética o teológica de Pablo, sino que simplemente pretendió un ejercicio de comprensión fenomenológica.

La lectura de Heidegger se centró en las dos cartas a los Tesalonicenses. La primera, como es sabido, es posiblemente el documento cristiano completo más antiguo que conservamos, mientras que la segunda es considerada por Heidegger como una carta auténtica, a pesar de las voces que ya en su tiempo impugnaban la autoría paulina. Para Heidegger, el Pablo que en ellas aparece es alguien que ciertamente no deriva sus ideas de las llamadas "religiones de misterios", pero que también es claramente independiente del judaísmo y del Jesús histórico.

Heidegger comparte con la intelectualidad alemana del momento una posición de clara distancia frente a lo que en su curso denomina el "fariseísmo judaíco". Al mismo tiempo, Heidegger parece estar al tanto de la crisis de la investigación histórica sobre Jesús, y sobre las tesis de Martin Kähler sobre la separación entre el Jesús histórico y el Cristo de la fe, que sería el único verdaderamente relevante para el cristianismo. ${ }^{21}$ De este modo, Heidegger subraya la originalidad de Pablo, que aparece como el representante de una "nueva religiosidad", distinta de la pagana y de la judía. Y esta nueva religiosidad es la que Heidegger quiere analizar fenomenológicamente.

Un elemento central de esa "nueva religiosidad" es el hecho de que los tesalonicenses han aceptado la predicación apostólica. Esta aceptación de la predicación apostólica se traduce en un saber de un "haber llegado a ser". ${ }^{22}$ Los tesalonicenses han dejado los ídolos, son ahora compañeros de Pablo, y su existencia se caracteriza por un caminar ante Dios. Este nuevo saber, esta nueva autocomprensión, es lo que caracteriza la nueva religiosidad, y lo que está en el origen de toda elaboración teológica en la historia del cristianismo.

${ }^{21}$ Es la famosa conferencia de M. Kähler, "Der sogenannte historische Jesus und der geschichtliche, biblische Christus" (Leipzig, 1892).

${ }^{22}$ Heidegger se refiere probablemente al egenéthete de 1Ts 2,14. 
Lo decisivo para el cristianismo, según Heidegger, no sería el dogma posterior, sino la experiencia cristiana de la vida, que sus análisis pretenden mostrar. Es importante subrayar, desde el punto de vista de Heidegger, que este "haber llegado a ser" que caracterizaría a la experiencia cristiana tiene una dimensión temporal, pues incluye la expectativa de la parusía. Sin embargo, para los cristianos esta expectativa está ya realizada por la venida de Jesús, de tal manera que la esperanza cristiana es distinta de cualquier otra expectativa.

Al romper con un tiempo determinado, el cristianismo habría reconfigurado la escatología judía. La nueva religiosidad cristiana estaría caracterizada por la temporalidad, pero por una temporalidad que no remite a un cuándo. Lo decisivo ya no sería el cuándo, sino la expectativa misma. La respuesta de Pablo a la inquietud de los tesalonicenses sobre el cuándo de la parusía no sería otra que la exigencia de permanecer sobrios y vigilantes.

Esta interpretación de la esperanza cristiana es lo que le condujo a Heidegger a afirmar la autenticidad de la segunda Carta a los Tesalonicenses, la cual no haría otra cosa que insistir en la expectativa como modo de vida que ha llegado a ser propio de los cristianos: si la espera de la parusía es un modo de existencia no tiene sentido la ociosidad bajo el pretexto de la inminencia de la venida del Mesías.

En esta traducción de las imágenes escatológicas usuales a una terminología filosófica existencial, que adelanta muchas tesis posteriores de Bultmann ${ }^{23}$, las representaciones específicas de la espera (fechas, imágenes apocalípticas) no tienen relevancia, como tampoco es importante la atribución de la figura del "anticristo" a realidades históricas concretas como el Imperio Romano.

Lo decisivo, para Heidegger, es la actitud expectante en sí misma, que tiene su sentido y su valor en su mismo ejercicio, anterior a toda teología y a toda visión del mundo. Esta nueva experiencia fáctica de la vida que caracteriza al cristianismo es algo que el creyente es consciente de no haber obtenido por sí mismo, por las propias fuerzas, sino que procedería de Dios. Por eso, su significatividad tiene como correlato al Dios que ha hecho posible este nuevo modo de ser.

\section{El Zubiri de "Helenismo y cristianismo"}

Las reflexiones de Heidegger sobre Pablo posiblemente ejercieron una importante influencia sobre el joven Zubiri, quien en el curso "Helenismo y cristianismo" acomete también una intepretación de los textos paulinos.

${ }^{23}$ Bultmann, "Neues Testament und Mythologie", 1, 15-48; Idem, "Zum Problem der Entmythologisierung”, 2, 179-208; Idem, "Zum Problem der Entmythologisierung”, Vol. 4-1, 20-27. 
En primer lugar, como Heidegger, Zubiri insiste en que su perspectiva es filosófica, y no teológica. Sin embargo, para justificar esta perspectiva, Zubiri no apela a la lectura fenomenológica de la experiencia fáctica de la vida, sino a la relevancia del cristianismo para la historia de la filosofía. No olvidemos que Zubiri es catedrático de historia de la filosofía en la Universidad Central de Madrid, y que la historia de la filosofía es el objeto de muchos de sus cursos en esos años.

En segundo lugar, al igual que Heidegger, Zubiri muestra un interés central por el "haber llegado a ser", es decir, por las implicaciones ontológicas del cristianismo. Se tratará precisamente de explicar aquello que Schleiermacher dejaba sin explicar en su interpretación de Pablo: la elevación de la existencia humana.

En tercer lugar, como Heidegger, Zubiri llama la atención sobre el hecho de que en Pablo nos encontramos con una comprensión especial del tiempo, que Zubiri califica como cualitativa y no lineal: es el tiempo marcado por los acontecimientos salvíficos.

Esto no significa que Zubiri asuma sin más el pensamiento de Heidegger, a quien en esa época se refiere como su "maestro". ${ }^{24}$ Ya en el curso "Helenismo y cristianismo" Zubiri habla de la "existencia religada" de Pablo. Y "religación" es precisamente un término con el que Zubiri marca, en el mismo año 1935, una importante distancia frente al análisis heideggeriano de la existencia. Según Zubiri, el ser humano no está "arrojado" (geworfen), sino "implantado" en la existencia, y la recibe como algo que se le impone.

Esta imposición de la existencia es lo que nos impulsa a vivir, y en lo que nos apoyamos para existir. No se trata, por supuesto, de un apoyo físico, sino de lo que nos hace ser. Estamos, por tanto, ante algo que es lo más nuestro, porque nos hace ser, pero que al mismo tiempo es lo más otro, porque nos hace ser. No se trata simplemente de que estemos obligados a ser, como dirá más adelante el existencialismo. Más bien estamos religados a lo que nos hace existir. En lugar de arrojada, la existencia humana está "religada por su raíz". ${ }^{25}$

Esta perspectiva posibilita que Zubiri tome, en el curso "Helenismo y cristianismo", una significativa distancia respecto de la interpretación de Pablo corriente

\footnotetext{
${ }^{24}$ Aunque ya en 1933 Zubiri no dudaba en considerar como "idiota" el coqueteo de Heidegger con el nacionalsocialismo. Ver a Zubiri, Cursos universitarios 2, 341.

${ }^{25}$ Idem, Naturaleza, historia, Dios, 224-225.

${ }^{26}$ Ver a Meyer, Die Auferstehung Christi: Die Berichte über Auferstehung, Himmelfahrt und Pfingsten, ihre Entstehung, ihr geschichtlicher Hintergrund, und ihre religiöse Bedeutung (1905).
} 
en su tiempo. La teología paulina no se fundaría en un sentimiento, como quería Schleiermacher, o en una "experiencia psicológica", como pretendía Arnold Meyer, otro autor citado por Zubiri. ${ }^{26}$ Según Zubiri, lo que tendríamos en Pablo sería más bien "un hecho religioso integral, que afecta al ser entero del hombre".

Esta afectación del ser entero del hombre es justamente lo que interesa a Zubiri. Frente a la imprecisa "elevación al infinito" de Schleiermacher, Zubiri quiere precisar tal dimensión ontológica que estaría en la base de la teología paulina. Y en este punto, para Zubiri, parece ser insuficiente la idea heideggeriana de un "haber llegado a ser" como nuevo modo de ser de las comunidades cristianas fundadas por el apóstol. A Zubiri le interesaba indagar el término concreto de ese "haber llegado a ser".

Es como si, ya en estos ańos, Zubiri estuviera apuntando a una toma de distancia frente a la concepción heideggeriana del ser humano, para interesarse en aquello que, en su filosofía madura, será descrito en términos de una articulación entre realidad y ser. En cualquier caso, en "Helenismo y cristianismo", Zubiri subraya que los cristianos han llegado a ser "hijos de Dios". No se habla en ese curso todavía de deificación o de deiformación, pero sí de la "filiación divina", cuyas implicaciones ontológicas Zubiri quiere analizar.

Y entonces, igual que Heidegger, Zubiri emprende un análisis filosófico de las epístolas paulinas. Ahora bien, aquí es significativa la epístola elegida por Zubiri. En lugar de atender, como Heidegger, a la correspondencia tesalonicense, en la que aparece en primer plano la cuestión del tiempo, ligada a la escatología, Zubiri se dirige a la Carta a los Efesios, en la que encuentra más elementos para abordar las cuestiones ontológicas. Por supuesto, como en Heidegger, la cuestión de la autenticidad de esta Carta juega en Zubiri un papel muy secundario, pues lo que le interesa en definitiva es explorar el impacto del cristianismo primitivo sobre la ontología.

No obstante, hay que señalar que la cuestión del tiempo no pasa desapercibida para Zubiri en su análisis de la Carta a los Efesios. Aquí es interesante observar que Zubiri destaca positivamente la impronta judía en la concepción del tiempo de Pablo. Desde el punto de vista del judaísmo, el tiempo está cualitativamente determinado por aquello que sucede en el mismo. Así, el Eclesiastés habla de "tiempo de guerra y tiempo de paz", "tiempo de amar y tiempo de odiar", etc. (Qo 3,8). En el caso de Pablo, el tiempo presente está caracterizado precisamente por la plenitud (pléroma) del acontecimiento de Cristo, y la filiación divina recibida por los creyentes. ${ }^{27}$

${ }^{27}$ Es el modo como Zubiri interpreta textos como Ef 1,23; 3,19 y 4,13. 
Frente a Heidegger, que tendía a despreciar el elemento judío en Pablo, Zubiri muestra en "Helenismo y cristianismo" un mayor conocimiento y valoración del mismo. Así, por ejemplo, Zubiri hace referencia a la mentalidad aramea presente en el Nuevo Testamento, o recuerda el hecho de que, para los judíos, la creación no es simplemente una "naturaleza", sino la primera obra de gracia.

Estos conocimientos sobre el judaísmo pueden deberse no solo a los estudios de Zubiri en esos años sobre lingüística e historia de las religiones, sino también, en concreto, a la influencia que sobre él ejerció el trabajo de Hans Von Soden sobre la verdad, del que Zubiri hizo buen uso posteriormente en su trabajo Sobre el problema de la filosofía. ${ }^{28}$ En su curso "Helenismo y cristianismo", Zubiri ya se refería a Von Soden, aunque señalando que había que tomarlo como exegeta, y no como teólogo.

En su análisis de la teología paulina, Zubiri no se limita a la Carta a los Efesios. Con frecuencia, esta es solamente un punto de partida que le sirve para adentrarse en distintos problemas teológicos y en las distintas posiciones que se han ido tomando respecto a ellos en la historia de la teología. Aunque Zubiri tiene claramente un interés ontológico en su análisis de la teología paulina, en el curso "Helenismo y cristianismo" no está en condiciones de proponer un sistema de conceptos metafísicos con el que dar cuenta de esa teología.

Más bien Zubiri se limita a señalar la insuficiencia de la ontología con la que clásicamente se han abordado las cuestiones teológicas. Así sucede, por ejemplo, con la mencionada idea de que la creación no es una naturaleza, sino una primera obra de gracia. Al mismo tiempo, Zubiri señala la dimensión ontológica del pecado, como algo que afecta al ser entero del hombre, confiriéndole una "existencia empecatada". ${ }^{29}$

Con esto, Pablo se situaría más allá de la concepción judía, para la cual el pecado sería simplemente una infidelidad al pacto. Pero esta existencia empecatada tampoco puede pensarse al modo griego, como una especie de defecto de la naturaleza. Es algo que se sitúa en otro nivel, que no es natural, sino existencial. En cualquier caso, de las consideraciones de Zubiri ya asoma una cuestión que tendrá un signifi-

${ }^{28}$ Ver a Von Soden, Was ist Wahrheit? Vom geschichtlichen Begriff der Wabrheit (1927). En Sobre el problema de la filosofía, 53n, Zubiri reconoce explícitamente su deuda con el trabajo de Von Soden, que ha continuado ejerciendo un influjo importante sobre la teología contemporánea.

${ }^{29}$ Aunque en "Helenismo y cristianismo" Zubiri cita muy positivamente el libro de L. Billot sobre el pecado, los conceptos con los que Zubiri explica la dimensión ontológica del mismo son muy distintos de los que se encuentran en el texto de Billot, quien habla en términos de una afectación, no de la naturaleza en general, sino de la naturaleza en cuanto transmisible a la posteridad. Ver a Billot, De personali et originali peccato, 140-144. Zubiri, que subrayó precisamente esas páginas del ejemplar de Billot, ya en 1934-1935 habla sin embargo en términos existenciales. 
cado decisivo en la teología católica del siglo XX, y que será el descubrimiento de que la gracia no es primero algo que se opone a la naturaleza, como una especie de sobrenaturaleza, sino algo que se opone al pecado.

En cualquier caso, si el pecado tiene una dimensión ontológica, también la tiene la santificación. Zubiri, obviamente, se opone a una concepción de la santificación que consistiera en una simple declaración forense, meramente externa al ser humano ${ }^{30}$; pero también se opone a concepciones de la santidad como la que había expuesto Rudolf Otto, en su conocido libro, tan influyente en la fenomenología de la religión. ${ }^{31}$

La santidad, para Zubiri, no es un mero ámbito de sacralidad, sino algo entitativo: se trata de ser hechos hijos de Dios. En cierto modo, se podría decir que estamos ante una nueva naturaleza, pero de nuevo Zubiri tiene que admitir que en realidad no es algo que se pueda comprender en términos de naturaleza y sobrenaturaleza. La santidad no se opone a la naturaleza, sino al pecado.

Frente a la existencia empecatada, tenemos la filiación divina. La redención consistiría precisamente en un acontecimiento ontológico, que sucede en cada individuo, aboliéndose así la distancia con lo sucedido en Cristo. Desde este punto de vista, la fe no puede ser considerada como algo subjetivo, sino que tiene ella misma una dimensión ontológica. Según Zubiri, la fe no sería otra cosa que la gracia misma, la cual consiste en hacernos hijos de Dios. Por eso la justificación, lejos de ser una atribución extrínseca, consiste en una verdadera regeneración de la naturaleza humana, expoliada por el pecado.

Desde este punto de vista, Zubiri puede señalar la originalidad de los "sacramentos" cristianos, por más que esta terminología sea ulterior a Pablo. Los sacramentos no serían meros ritos de purificación, como ciertas ceremonias mistéricas que se compararon con el bautismo. Pero tampoco serían meros signos externos de la salvación. Zubiri entiende que los sacramentos contienen la gracia que significan ${ }^{32} \mathrm{o}$ que son "causas eficientes de la gracia que contienen".

\footnotetext{
${ }^{30}$ Aunque en honor a la verdad hay que señalar que la concepción protestante clásica ligaba el momento forense a la "justificación", mientras que admitía en cambio la participación del ser humano y su transformación real en lo que denominaba "santificación".

${ }^{31}$ Zubiri tenía en su biblioteca una edición de 1932. Ver a R. Otto, Das Heilige (München, 1932). Tanto Heidegger como Zubiri coinciden en distanciarse de Rudolf Otto, quien en cambio fue asumido con entusiasmo por otros sectores de la fenomenología religiosa.

${ }^{32}$ Zubiri alude posiblemente al canon 6 de los artículos de Trento. Ver DS 1606, en Denzinger y Schönmetzer, Enchiridion symbolorum, definitionum et declarationum de rebus fidei et morum, 382.
} 
En consecuencia, Zubiri puede afirmar que los sacramentos poseen una dimensión ontológica, lo cual se inserta en su perspectiva general sobre el cristianismo como verdadera transformación del ser humano. En este punto, Zubiri no se refiere a la teología de los misterios de Odo Casel, que simplemente expone una doctrina católica común, con la terminología clásica. Lo único que Zubiri hace es señalar que las diferencias en la teología católica se plantean en el modo como se entienda que los sacramentos "contienen” la gracia.

Sin embargo, Zubiri afirma explícitamente, en "Helenismo y cristianismo", que no va a entrar en esta cuestión. Y es difícil pensar que, en su curso en la Universidad Central de Madrid, Zubiri no quisiera citar a Casel por motivos de prudencia, como sucederá en las publicaciones posteriores a la guerra civil española: en su curso oral Zubiri no tuvo ningún empacho en utilizar a lo más granado de protestantismo contemporáneo, del liberalismo y del modernismo. ${ }^{33}$

En cualquier caso, del curso "Helenismo y cristianismo" llama la atención la gran variedad de las influencias recibidas críticamente por Zubiri: Schleiermacher y su idea del cristianismo como religión, la escuela de Tubinga, la teología liberal y modernista, la escuela escatológica, la escuela de historia de las religiones, la relevancia teológica de la filosofía de Heidegger, los trabajos de Lagrange y de Von Soden.

También es interesante observar que estamos ante un estrato anterior a las influencias teológicas que aparecen en el texto posterior "El ser sobrenatural". Todavía no hay referencias a Stoltz y a Keller, con los que posiblemente entró en contacto durante su estancia en Roma. Tampoco se tiene en cuenta a la patrología griega, en la que Zubiri posiblemente profundizó posteriormente, durante su estancia en París. Estamos también en un momento anterior a la Teología dogmática de Michael Schmaus, cuya primera edición es del año 1937. También faltan referencias a la teología de los misterios, como sí aparecerán (aunque implícitas) en el texto de Naturaleza, historia, Dios sobre "El ser sobrenatural".

Sin embargo, las influencias consignadas en "Helenismo y cristianismo" son decisivas para entender la posterior evolución de Zubiri en el campo teológico. Las preocupaciones ontológicas, en las que hay que destacar el influjo de Heidegger, han lanzado a Zubiri hacia una interpretación del cristianismo en términos de lo que des-

\footnotetext{
${ }^{33}$ En el curso "Helenismo y cristianismo", más que el influjo de Odo Casel, parece haber, respecto de los sacramentos, algún paralelismo con una doctrina que posteriormente defendió Warnach, para evitar la alternativa entre poner a los que reciben el sacramento en el pasado, o sacar la obra redentora del pasado para ponerla en el presente. Warnach defendió que los sacramentos tendrían lugar en un "hoy intemporal". Ver a Warnach, "Zum Problem der Mysterien Gegewart”, en Liturgisches Leben 5 (1938): 9-39.
} 
pués llamará deificación y, en su obra madura, "deiformación”. Esta interpretación ontológica de la "filiación divina" a partir de la Carta a los Efesios es el legado fundamental del curso "Helenismo y cristianismo", que da la pauta para la asunción de influencias posteriores, como las ya mencionadas.

\section{Las preocupaciones filosóficas de Zubiri}

Este punto de vista nos puede ayudar a entender el sentido del texto de 1944 sobre "El ser sobrenatural", que lleva por subtítulo "Dios y la deificación en la teología paulina". Una simple aproximación al texto, que se presenta como "unas cuantas reflexiones en torno a ciertos pasajes de la Epístola a los Romanos" ${ }^{\text {"3 }}$, en seguida nos muestra que, como el mismo Zubiri reconoce, ese "en torno" puede implicar el "entorno" neotestamentario entero.

De hecho, Zubiri cita todo el corpus paulinum y también hace un uso decisivo de los textos joánicos, como la afirmación de que Dios es amor. ${ }^{35} \mathrm{Al}$ mismo tiempo, también nos dice que lo que pretende es una "exposición de unos textos neotestamentarios, tal como fueron visto por la tradición griega" ${ }^{36} \mathrm{Y}$ ciertamente, en el artículo de Zubiri llaman la atención las múltiples referencias a la patrología griega, con frecuencia contrapuesta a la latina.

También nos engañaríamos si pensaráramos que Zubiri se limita a los padres griegos; en momentos decisivos utiliza a ciertos autores latinos, a los que considera cercanos a la tradición griega, como Ricardo de San Víctor o Alejandro de Hales. No solo eso: como hemos dicho, tampoco faltan las referencias, explícitas o implícitas, a autores católicos contemporáneos, como Stolz, Schmaus, o Casel.

Todo esto dificulta la interpretación del texto. ¿Estamos ante una exposición histórica o sistemática? Si es histórica -como Zubiri señala ${ }^{37}$ - ¿por qué esa amplitud de autores, y esa presentación sistemática de la teología? ¿Verdaderamente se expone la posición de Pablo, o las ideas de algún teólogo griego? ¿Se puede exponer sistemáticamente toda la patrología griega? ¿O estamos más bien ante las ideas de Zubiri? Pero si es una exposición sistemática, ¿por qué Zubiri se distancia de ella?

\footnotetext{
${ }^{34}$ Zubiri, Naturaleza, historia, Dios, 457.

${ }^{35}$ Ver 1Jn 4,8. Aunque Zubiri también alude a algunos textos paulinos en los que se habla del "Dios de amor" o del "hijo amado" (2Co 13,11; Ef 1,6; Col 1,13).

${ }^{36}$ Zubiri, Naturaleza, historia, Dios, 456.

${ }^{37}$ Ibid.
} 
Para comenzar a aclarar esto, comencemos con el recurso a la teología griega. Zubiri mismo nos da una clave decisiva cuando nos dice que "el estado actual de muchas preocupaciones filosóficas descubre en la teología griega intuiciones y conceptos de fecundidad insospechada". ${ }^{38}$ Zubiri ciertamente es un filósofo, y su aproximación a la teología no se hace al margen de esta condición. Es algo que ya vimos en "Helenismo y cristianismo", y que se mantiene en este texto. Pues bien, ¿¿cuáles son las preocupaciones filosóficas a las que se refiere Zubiri? Mencionemos, al menos, algunas de ellas.

- En primer lugar, la filosofía se encontraba ante la crisis de la subjetividad moderna, cuestionada por el desfondamiento de toda conciencia en nombre de la existencia, tal como sucedía en la obra de Heidegger. No se trata solamente de mostrar que la conciencia está intencionalmente dirigida hacia los objetos, sino que toda la existencia humana está caracterizada por la apertura al ser, de modo que el existente es precisamente el "ahí del ser" (dasein).

Con esto, Zubiri entiende que se abre todo un nuevo horizonte filosófico, superador de la filosofía medieval y moderna. ${ }^{39}$ Pues bien, según Zubiri, la teología griega no partiría del "hombre interior" y de sus aspiraciones de felicidad, como sucedía en Agustín, sino vería al ser humano en el contexto del cosmos entero, de modo que los conceptos teológicos tendrían otro significado. ${ }^{40} \mathrm{El}$ pecado, para los griegos, no sería una simple malicia de la voluntad, sino una mácula de la creación, mientras que el amor, más que una aspiración del alma, sería más bien "el fondo metafísico de toda actividad". ${ }^{41}$ Se trata de algo que, como vemos, conecta con las consideraciones ya formuladas en el curso "Helenismo y cristianismo".

- En segundo lugar, Zubiri sitúa la "metafísica de la subjetividad”, denunciada por Heidegger, en un horizonte más amplio, que él considera el "horizonte de la creación" o "de la nihilidad". La idea judeo-cristiana de creación habría conducido a la filosofía occidental a considerar el ser desde su posible nihilidad. Se trata, obviamente, de una crítica que afectaría incluso al mismo Heidegger de aquella época. ${ }^{42}$

${ }^{38}$ Ibid., 459.

${ }^{39}$ Ibid., 284-287.

${ }^{40}$ Desde ese punto de vista, no tiene mucho sentido que el análisis teológico del texto sobre los padres griegos sea introducido con una consideración sobre las ansias humanas de felicidad: precisamente ése es el punto de partida que Zubiri no desea.

${ }^{41}$ Zubiri, Naturaleza, historia, Dios, 458.

${ }^{42} \mathrm{Idem}$, Los problemas fundamentales de la metafísica occidental, 35. 
Por supuesto, no se trata de que la teología griega no piense en la creación. Sin embargo, a diferencia de Agustín, la teología griega no partiría de la mutabilidad del ser, y por tanto de su contingencia, sino más bien del ser efusivo de Dios. El punto de partida griego no sería la potencial nihilidad de las criaturas, sino más bien la sobreabundancia del ser de Dios, que se desborda en la creación.

Desde este punto de vista, las criaturas reflejan el ser de Dios. Y aquí aparece entonces un concepto clave en el trabajo de Zubiri, que es el de "causalidad formal", a diferencia de la causalidad eficiente. En la causalidad formal, característica de los padres griegos, lo decisivo serían los modos en los que el efecto reproduce la causa. ${ }^{43}$ - $\quad$ En tercer lugar, esta ontología que Zubiri atribuye a los padres griegos tendría un origen muy concreto, que sería Aristóteles. Las lecturas fenomenológicas de Aristóteles, realizadas por Zubiri en continuidad con las de Heidegger, contribuyeron a determinar su propio camino filosófico, y su distanciamiento del filósofo alemán. ${ }^{44}$ Frente al "Aristóteles latino", propio de la filosofía y la teología escolásticas, Zubiri encuentra en los padres griegos mayor cercanía al pensamiento originario del Estagirita.

Según Zubiri, el supuesto aristotelismo de la teología escolástica es, muchas veces, en realidad, un platonismo, mientras que los conceptos utilizados por los padres griegos estarían más cerca del auténtico Aristóteles. ${ }^{45}$ En esto, Zubiri defiende una tesis completamente opuesta a la de Michael Schmaus, quien tendía a encuadrar a los padres griegos dentro del platonismo. ${ }^{46}$

- $\quad$ En cuarto lugar, en 1935, Zubiri se había referido, de manera muy positiva, a Laction de Maurice Blondel, pero señalando que sus conceptos tendrían que ser llevados al terreno claro de una ontología. ${ }^{47}$ Es algo que, a estas alturas, ya no nos puede extrañar en el pensamiento de Zubiri.

Pues bien, Zubiri entiende que la patrística griega desarrolló una interpretación "activista" de la metafísica de Aristóteles; mientras que los latinos habrían interpretado el acto (enérgeia) aristotélico como actualidad, siguiendo más bien modelos físicos,

\footnotetext{
${ }^{43}$ Idem, Naturaleza, historia, Dios, 474-475.

${ }^{44}$ Es lo que he tratado de mostrar en mi estudio sobre "El eslabón aristotélico", 5-36.

${ }^{45}$ Zubiri, Naturaleza, historia, Dios, 459.

${ }^{46}$ Schmaus siguió defendiendo esta interpretación en las sucesivas ediciones de su Katholische Dogmatik. Ver, por ejemplo, su Volumen IV/1, 36ss.
}

${ }^{47}$ Zubiri, Naturaleza, historia, Dios, 434. Como es sabido, en la obra madura de Zubiri se distingue entre la metafísica (referida a la realidad) y la ontología (referida al ser). A la altura de los años 30 y 40 , Zubiri todavía no ha articulado claramente metafísica y ontología, y aquí utilizaremos los términos sin la precisión conceptual requerida en etapas ulteriores. 
los griegos, partiendo de modelos biológicos, habrían pensado el acto como actividad constitutiva, siendo la actualidad solamente su momento terminal. ${ }^{48}$ Precisamente esta ontología activista sería apta para pensar el acto puro de Dios como amor, es decir, como una actividad efusiva que se plasma, ad intra, en las procesiones trinitarias y, ad extra, en la creación y en la deificación, la cual incluye, para Zubiri, tanto la encarnación como la santificación.

- $\quad$ En quinto lugar, Zubiri quiere subrayar que esta actividad constitutiva es propia de un ser concreto y delimitado. Frente a la interpretación de la ousía aristotélica como "substancia" que suporta sus accidentes, o como "entidad" en general, Zubiri quiere subrayar que se trata de un ente concreto, dotado de riqueza y de suficiencia para ser lo que es. ${ }^{49}$

Pues bien, Zubiri encuentra que los padres griegos han leído de esta manera a Aristóteles, pues la concepción activa del ser no lo separa de las realidades concretas, sino que permite verlo como "actividad originaria unificante". ${ }^{50} \mathrm{La}$ unidad del ser no sería la mera negación lógica de la división, sino la unificación activa de todas las propiedades de una cosa. La ousía, para los padres griegos, sería la unidad del ser en la riqueza de sus notas ${ }^{51}$, y la esencia no sería el mero correlato de una definición, sino más bien "la actividad del ser mismo en cuanto raíz de todas sus notas". 52

- $\quad$ En sexto lugar, eso significa que la primera de las cuestiones planteadas puede ser abordada desde un nuevo punto de vista. La teología sistemática difícilmente puede prescindir del concepto de persona. Se trata de un concepto esencial para la cristología y para la teología trinitaria. Ahora bien, la teología no tiene que pensar la persona como sujeto, ni como complemento de la naturaleza. Según Zubiri, los padres griegos entendieron la persona como un principio para la subsistencia de la propia naturaleza. ${ }^{53}$

No solo eso. Zubiri puede recurrir también a teólogos occidentales, como Ricardo de San Víctor, que considera cercanos a la perspectiva griega. Este teólogo pensó la naturaleza como una sistencia, mientras que la persona sería el modo de tener naturaleza, su origen, su ex. Y, como dice Zubiri, "creó entonces la palabra existencia como

\footnotetext{
${ }^{48}$ Zubiri, Naturaleza, historia, Dios, 465-468.

${ }^{49}$ Ibid., 65-66, 121-125.

${ }^{50}$ Ibid., 468.

${ }^{51}$ Ibid., 469.

${ }^{52}$ Ibid., 474.

${ }^{53}$ Ibid., 477.
} 
desginación unitaria del ser personal. Aquí existencia no significa el hecho vulgar de estar existiendo, sino que es una característica del modo de existir: el ser personal" ${ }^{54}$ Sin duda, es una concepción de la existencia que no deja de recordarnos de nuevo a Heidegger, que también reserva el término para el ser humano.

\section{La Trinidad y la creación}

Estas consideraciones nos permiten entender el sentido, enormemente amplio, en el que Zubiri se refiere a la teología griega. Los padres griegos son considerados desde una perspectiva filosófica, como respuesta a ciertas preguntas del pensamiento contemporáneo, e incluyendo en su perspectiva la obra de autores latinos o contemporáneos que, por algunas razones, por remotas que sean, pueden ser considerados como cercanos a la perspectiva griega.

Aquí hay que tener en cuenta que la teología griega es tomada como un todo unitario, sin consideración de la gran diversidad de perspectivas dentro de la misma. En cierto modo, se trata de un modo de proceder que era común a varios autores, como Stolz o Schmaus, para quienes la contraposición entre la teología latina y la teología griega, que encontramos ya en los estudios de Regnon ${ }^{55}$, no obedece a preocupaciones meramente históricas, sino a la necesidad fuertemente sentida de renovar la teología católica introduciendo acentos que difícilmente podían ser rechazados como heréticos, por más que fueran extraños a la teología escolástica al uso.

Por eso, no interesa subrayar la diversidad de la teología griega, sino más bien tomarla como un todo unitario y distinto de la teología occidental; y por eso mismo, en el tratamiento de Zubiri, caben autores que no son griegos, pero que resultan relevantes en la medida en que exponen líneas de pensamiento no aprovechadas en Occidente.

El mismo Ricardo de San Víctor, cuando desarrollaba su innovadora (aunque desaprovechada) terminología, insistía precisamente en que "no somos griegos". ${ }^{56}$ Zubiri no hace una historia de la teología griega sin más. Él se ha enfrentado, en los años anteriores, a una crisis religiosa personal, al hilo del modernismo, y también, posteriormente, a una evolución filosófica que le ha abierto posibilidades nuevas para pensar el cristianismo, pero que exigen pensarlo con un instrumental conceptual nuevo.

\footnotetext{
${ }^{54}$ Ibid., 477-478.

${ }^{55}$ Ver a Th. de Régnon, Études de théologie positive sur la Sainte Trinité (4 vols.). La tesis de Régnon, en toda su amplitud, ha sido posteriormente cuestionada.

${ }^{56}$ Ricardo de San Víctor, De Trinitate IV, 4 ("Graeci non sumus").
} 
En este sentido, más que una exposición histórica de la patrología griega, tenemos una interpretación de la ontología presuntamente implícita en los teólogos griegos. Los elementos centrales de esta interpretación son el concepto de ser como actividad efusiva pura, especialmente apta para pensar el ser de Dios como amor, y la causalidad formal, según la cual el efecto, de maneras diversas (creación, encarnación, santificación) reproduce la causa.

No es que los padres griegos de manera explícita hayan utilizado los "prolegómenos" 57 o "prenontados" 58 filosóficos que Zubiri expone de manera sistemática, sino que Zubiri entiende que estos conceptos pueden servir para exponer la relevancia filosófica de la patrística griega.

En esta exposición cabe también la teología contemporánea a Zubiri, precisamente en la medida en que esa teología comparte con él las apelaciones a la teología griega en general. Es lo que sucede, por ejemplo, con la teología trinitaria expuesta por Zubiri, en la que sin duda se hace presente el diagnóstico de Regnon sobre la diferencia entre la teología griega, que partiría de las personas, y la teología latina, que partiría de la naturaleza divina. Según Zubiri, "el amor y el movimiento como pura actividad es el principio de la vida trinitaria". 59

Por eso mismo, los griegos partirían de la índole de cada una de las personas, y tratarían de pensar cómo esas tres personas son una misma cosa. ${ }^{60} \mathrm{Y}$ esto significaría que, para los griegos, "cada persona no puede existir sino produciendo la otra, y del concurso de esta producción personal queda asegurada (si se me permite la expresión) la idéntica naturaleza de un solo Dios". ${ }^{61} \mathrm{Y}$, en este punto, Zubiri no solo cita a los griegos, sino también - de nuevo- a Ricardo de San Víctor y a la escuela franciscana (Durando, Herveus Natalis). ${ }^{62}$

Entre los autores contemporáneos, habría que citar el tratado sobre la Trinidad de Anselm Stolz y la teología dogmática de Michael Schmaus. ${ }^{63}$ En ellos tenemos, bajos referencia explícita a estas fuentes griegas y occidentales, un tratado de Dios enfocado como tratado sobre la Trinidad. Como dirá después Karl Rahner, Stolz y

\footnotetext{
${ }^{57}$ Zubiri, Naturaleza, historia, Dios, 476.

${ }^{58}$ Ibid., 478.

${ }^{59}$ Ibid., 484.

${ }^{60}$ Ibid., 482.

${ }^{61}$ Ibid., 483.

${ }^{62}$ Ibid.

${ }^{63}$ Ver a Stolz, De Sanctissima Trinitate, y a Schmaus, Katholische Dogmatik, Vol. 1.
} 
Schmaus representan algunas de las poquísimas y honrosas excepciones a la típica escisión escolástica entre el tratado De Deo uno y el tratado De Deo trino. ${ }^{64}$

Otro ejemplo puede ser la consideración de la Trinidad ad extra. Como vimos, el concepto de causalidad formal sirve a Zubiri para sistematizar el modo como los griegos han pensado la creación y la deificación (la cual, en el esquema de Zubiri, incluye la encarnación y la santificación) como distintos modos en los que la obra trinitaria queda reflejada en sus efectos.

Según Zubiri, la teología griega no conoce las llamadas "apropiaciones" por las que la teología escolástica atribuyó las distintas obras de la Trinidad a una de las personas trinitarias. ${ }^{65}$ La Trinidad actuaría siempre de forma conjunta, tanto en la creación como en la encarnación y en la santificación. ${ }^{66} \mathrm{Y}$ esto significa, por ejemplo respecto de la creación, que los padres griegos "no pierden de vista la unidad radical de las acciones divinas, que se reducen... a su agápe, a su amor. La diferencia está en que ad intra este agápe es el ser mismo divino, mientras que ad extra es el imperio con el que liberalmente quiere producir otras cosas" ${ }^{67}$

Dicho en otros términos, respecto de la creación: "la creación es la Trinidad actuando causalmente ad extra" ${ }^{68}$ Es decir, Zubiri afirma lo que más adelante se vendrá a llamar la identidad entre la Trinidad inmanente y la Trinidad económica. Esta tesis, que fue popularizada por Rahner, se encuentra recogida, como "tradición de los padres”, en Anselm Stolz, uno de los teólogos utilizados por Zubiri. ${ }^{69}$

Sucede que Zubiri asume tales afirmaciones teológicas en la perspectiva ontológica de la causalidad formal, sentada en los prolegómenos filosóficos de su estudio. En el caso concreto de la creación, la causalidad formal consiste desde luego en la producción transcendente de cosas que no son Dios. Sin embargo, la causalidad formal implica una reproducción de la causa en el efecto. Por eso mismo, el acto creador entraña una progresiva "relucencia" de Dios fuera de sí mismo. Esta relucencia no im-

${ }^{64}$ Ver a Rahner, "Der dreifaltige Gott als transzendenter Urgrund der Heilsgeshichte", 2, 317-401, específicamente, 323. El texto fue conocido y subrayado por Zubiri.

${ }^{65}$ Zubiri, Naturaleza, historia, Dios, 494.

${ }^{66}$ Ibid., 494, 505, 520, 526.

${ }^{67}$ Ibid., 494.

${ }^{68}$ Ibid., 495.

69 “... traditio patrum... principium tenet, oiconomiae internae correspondere oiconomiam externam" (Stolz, De Sanctissima Trinitate, 130). Posiblemente Stolz es el "ilustre teólogo" al que Zubiri se refiere en Naturaleza, historia, Dios, 494. 
plica un panteísmo, precisamente porque hay un momento de nihilidad que distingue a la Trinidad creadora de lo creado.

Sin embargo, el ser creado, igual que Dios mismo, es constitutivamente acción, porque su esfuerzo consiste en ser el que es, manteniéndose en sí mismo, y tendiendo hacia Dios. ${ }^{70} Y$ es que todo lo que las cosas tienen de ser positivo, se debe a la presencia de Dios en ellas. De ahí que Zubiri pueda retomar, ahora desde el punto de vista de su lectura ontológica de la teología griega, su cita paulina favorita: vivimos, nos movemos, y somos en él. ${ }^{71}$ En el marco de esta ontología de la creación, Zubiri asume un esquema sobre la jerarquía ontológica de los distintos seres que, como Guillermina Díaz ha mostrado, proviene de un manuscrito de Warnach sobre los distintos grados de ser en el Nuevo Testamento. ${ }^{72}$

No obstante, de nuevo, aquí lo esencial no es la positividad de la jerarquía de los seres, sino la inserción de la misma en una magnífica interpretación de la ontología de los padres griegos. Y esta interpretación y sistematización proviene del propio Zubiri, cuyo genio filosófico supera sensiblemente al de sus "fuentes".

\section{La deificación}

Algo parecido puede decirse del tratamiento de Zubiri de la deificación, que divide entre encarnación y santificación, y que entiende de nuevo como diversos modos de la causalidad formal.

- $\quad$ En el caso de la encarnación, Zubiri recurre directamente a Pablo, en concreto al himno cristológico del capítulo segundo de la Carta a los Filipenses; y aquí desarrolla una interesante interpretación ontológica de los términos paulinos morphé y skhéma. La morphé sería la configuración intrínseca de una cosa, y por tanto, su esencia real, su naturaleza. Desde esta ontología "fuerte", Pablo estaría afirmando la identidad de la naturaleza del Hijo con la de Dios. En cambio, el skhéma sería más bien el modo de ser individual. Con esto, Pablo estaría afirmando que el Hijo no solo tomó la naturaleza humana, sino que se hizo un individuo humano concreto, "como todos los de su época, medio y condición". ${ }^{73}$

Del mismo modo, Zubiri interpreta ontológicamente el "despojarse de sí mismo" del Hijo, y su "tomar" una naturaleza humana. Según Zubiri "este tomar y despojarse

\footnotetext{
${ }^{70}$ Zubiri, Naturaleza, historia, Dios, 496-497.

${ }^{71}$ Ibid., 497.

${ }^{72}$ Díaz, Teología del misterio en Zubiri, 78 ss.

${ }^{73}$ Zubiri, Naturaleza, historia, Dios, 509.
} 
tiene un sentido estrictamente ontológico, y no meramente atributivo" ${ }^{74} \mathrm{Y}$ el sentido ontológico consistiría en subrayar que la encarnación no es mezcla o emulsión de dos naturalezas, sino una sola persona con dos naturalezas perfectamente distintas.

Por supuesto, en la teología de los padres griegos no faltan tendencias, como la de Cirilo de Alejandría, que tienden a afirmar más bien la unidad de las naturalezas. Zubiri, en cambio, resalta calcedonianamente la distinción de las naturalezas, al tiempo que recoge la posibilidad de una "comunicación de idiomas". ${ }^{75}$

- En el caso de la encarnación, como también en el caso de la Trinidad, Zubiri echa mano del concepto de persona de Ricardo de San Víctor. Si la persona consiste en "ex-sistencia", lo decisivo es precisamente el ex-, la relación de origen, el modo de tener la propia sistencia, la propia naturaleza. En el caso de la Trinidad, los tres modos del ex-serían "las tres personas cuya mutua implicación asegura su idéntica sistencia natural". ${ }^{76}$ En el caso de la encarnación,

...la persona divina tiene esta naturaleza singular humana porque el Hijo la 'toma' directamente para sí... la naturaleza singular de este joven israelita está asumida por la persona del Hijo, de tal suerte que esta persona es principio de subsistencia, no solamente para la morphé divina, sino también para esta morphé humana. ${ }^{77}$

El resultado es entonces que "cuanto es y hace este hombre concreto Jesús es de Dios, en sentido ontológico, es divino".$^{78}$ La terminología existencial del victorino, unida a sus propias consideraciones históricas y ontológicas sobre la morphé, sirve a Zubiri para conceptuar un problema teológico. De fondo, sin embargo, está la interpretación del ser como actividad pura, intepretación que utiliza para situar ontológicamente el problema del monoteletismo.

Si el ser se interpreta como acción, nos situamos en un plano muy anterior y distinto de toda facultad operativa. Desde este punto de vista, la voluntad sería algo perteneciente a la naturaleza y no a la persona. ${ }^{79}$ Así puede Zubiri justificar la posición teológica triunfante en los concilios de la antigüedad: si en Cristo hay dos naturalezas, hay también dos voluntades. Más allá de los problemas históricos y teológicos implicados en este concepto, lo importante es notar, de nuevo, que Zubiri

\footnotetext{
${ }^{74}$ Ibid., 510.

${ }^{75}$ Ibid., 511-512.

${ }^{76}$ Ibid., 492.

77 Ibid., 512.

${ }^{78}$ Ibid., 513.

${ }^{79}$ Ibid.
} 
es capaz de utilizar magistralmente la interpretación de Aristóteles apuntada en los prenotandos filosóficos de su trabajo para resolver un problema de teología.

La santificación, desde el punto de vista de la causalidad formal, es otra obra de la Trinidad ad extra, que por el Espíritu imprime en el alma la imagen del Hijo. ${ }^{80}$ A diferencia de las concepciones cosificantes de la escolástica, la gracia es pensada primero como inhabitación de la Trinidad en el alma del justificado. ${ }^{81}$ Ahora bien, esta inhabitación tiene un efecto ontológico en el ser humano, que Zubiri trata de pensar con el concepto de héxis, que ya aparecía en el curso "Helenismo y cristianismo" y que tendrá una larga carrera en su itinerario filosófico.

La héxis no es simplemente un hábito, sino un modo de habérselas con las cosas, y por tanto "una segunda naturaleza, una reconformación estable de nuestra propia naturaleza humana" ${ }^{82}$ Esta "segunda naturaleza deiforme" ${ }^{83}$ conlleva una unificación de nuestro ser con el ser de Dios. Y este ser, entendido por Zubiri como actividad pura, consiste precisamente en el amor. Si Pablo dice que este amor no falla nunca, es precisamente, según Zubiri, porque ese amor es el amor eterno. ${ }^{84} \mathrm{El}$ pecado, visto desde este punto de vista, no es una mera falta moral, sino más bien como algo que se opone al amor de Dios, y por tanto como una mácula ontológica que afecta al universo entero.

Desde esta perspectiva, no cabe duda de que se podría decir, como en el curso "Helenismo y cristianismo", que la creación es la primera gracia, lo que obligaría a replantear la relación clásica entre naturaleza y gracia. Sin embargo, Zubiri hace eco, en este punto, de las preocupaciones propias de la nouvelle théologie francesa.

Esta corriente teológica, inspirada por la filosofía de Blondel, quiso evitar la impresión de que la gracia fuera algo perfectamente accesorio ("como un sombrero") respecto de la naturaleza humana, al tiempo que se la declara necesaria para la salvación. Para eso, autores como Henri de Lubac retomaron el concepto tomista de un "deseo natural" (desiderium naturale) de la visión de Dios, para subrayar que sin la satisfacción de este deseo la obra del creador habría fallado. ${ }^{85}$ Los trabajos Lubac

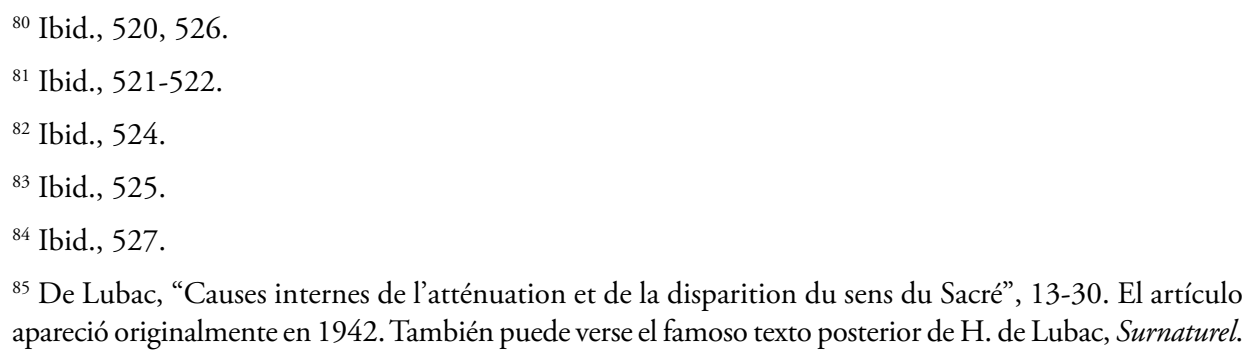


terminaron provocando una reacción del santo oficio después de la Guerra Mundial, pues obviamente una gracia que Dios debe al ser humano ya no es gracia.

Zubiri, en su trabajo de 1944, refleja preocupaciones semejantes a las de Lubac: la relación entre la naturaleza y la gracia no puede consistir simplemente en la superposición o estratificación de dos entidades, de modo que la gracia sería, como dice Zubiri, "una especie de ducha". ${ }^{86}$ A pesar del mismo diagnóstico crítico sobre las concepciones usuales de la gracia, Zubiri no recurre al desiderium naturale de Tomás. Más bien señala que, en la tradición griega, la gracia implica una transformación del ser entero del hombre. Del mismo modo que en la encarnación, la naturaleza humana queda asumida por la persona del Hijo, en la satificación, la gracia absorbería el ser del hombre en una unidad superior y transcendente. ${ }^{87}$

\section{Administrador de los misterios de Dios}

En conjunto, podemos decir que el texto de 1944 reasume la perspectiva del curso "Helenismo y cristianismo", consistente en interpretar el cristianismo desde el punto de vista de la transformación ontológica del ser humano. Es un punto de vista que Zubiri mantendrá hasta el final de sus días, cuando la "deiformación” sea el término técnico que sustituya a la deificación.

En 1944, ya Zubiri consigue integrar las intuiciones del curso "Helenismo y cristianismo" en una propuesta ontológica coherente, desde la que se abordan los grandes temas de la teología cristiana. En el punto de partida de esa interpretación del cristianismo sigue estando una lectura ontológica de Pablo, y precisamente por ello, el texto de 1944 tiene como subtítulo "Dios y la deificación en la teología paulina".

Desde el punto de vista de Zubiri, el apóstol de los gentiles sería el autor de una "catequesis viviente" destinada a la constitución de comunidades cristianas, agrupadas en torno de Cristo. Según Zubiri, para Pablo, el fundamento de estas comunidades o iglesias no sería "la participación en ciertos ritos" (como quiso la escuela de historia de las religiones) o cierto "régimen de vida práctica" ${ }^{8}$, sino algo más radical, que explica todo lo anterior.

Para Pablo, el fundamento de las iglesias consistiría "ante todo en una transformación radical de nuestra existencia entera, consecuencia, a su vez, de una trans-

\footnotetext{
${ }^{86}$ Zubiri, Naturaleza, historia, Dios, 528.

${ }^{87}$ Ibid., 528-529.

${ }^{88}$ Ibid., 460.
} 
formación de nuestro ser entero, de una deificación por su unión a Cristo" ${ }^{89}$ El texto nos muestra fehacientemente la voluntad de ir más allá de Heidegger: la existencia se funda sobre el ser humano concreto. En esta gran perspectiva ontológica se integra también una teología de los sacramentos. Para Zubiri, Pablo no es solo el teólogo de la deificación, sino también, utilizando una expresión paulina, un "administrador de los misterios de Dios" (1Co 4,1).

Muy pocos exegetas admitirían hoy que el término "misterio", en Pablo, se refiera a los sacramentos. Esa expresión tampoco designa primero lo desconocido o lo inexcrutable. Zubiri sabe bien que el primer sentido de la expresión "misterio" es el de la "acción sobrenatural de Dios en el mundo" o "el ordenamiento del plan de nuestra salud eterna", o "el arcano de su voluntad". Solo en un sentido derivado, tendría el término "misterio" el significado de lo incomprensible intelectualmente. ${ }^{90}$ Estos sentidos, primario y secundario, del término "misterio" son frecuente en los escritos paulinos $^{91}$, en los cuales se llega a afirmar que el misterio por excelencia no es otro que Cristo ( $\mathrm{Col} 2,2)$.

Más problemático resulta, desde el punto de vista de la exégesis actual, la idea de que, para Pablo, los misterios designaban también a los sacramentos o que, al menos, ese sentido sacramental "no esté excluido" del término paulino, como Zubiri quiere. ${ }^{92}$ Como es sabido, el término griego mystérion fue usualmente traducido al latín como sacramentum. Zubiri parece enteder que el misterio de Dios del que habla Pablo se concretaría en los sacramentos, en los cuales se produciría la unión con Cristo en que consiste nuestra deificación. Es la idea que Zubiri expone en el artículo que

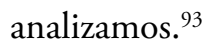

En cualquier caso, para entender la posición de Zubiri, hay que tener en cuenta que él se aproxima a la doctrina sobre los sacramentos dentro de su perspectiva general sobre la "deificación" como elevación ontológica, y no al revés. No se trata de que a Zubiri le sobrevenga la influencia de la teología de los misterios, y de ahí entienda al cristianismo como "deificación". El proceso es justamente el inverso: ya en el curso "Helenismo y cristianismo", Zubiri ha tratado de pensar en términos

\footnotetext{
${ }^{89}$ Ibid., 461.

${ }^{90}$ Ibid.

${ }^{91}$ Ver Rm 11,25; 16,25; 1 Co 2,1.7; 4,1; 13,2; 14,2; 15,51; Ef 1,9; 3,3-4.9; 5,32, 6,19; Col 1,26-27;

2,$2 ; 4,3 ; 2$ Ts 2,$7 ; 1 \mathrm{Tm} 3,9.16$.

${ }_{92}$ Zubiri, Naturaleza, historia, Dios, 530.

${ }^{93}$ Ibid., 461-462.
} 
ontológicos, desde una lectura de la Carta a los Efesios, lo que en Schleiermacher era una vaga elevación al infinito.

Ahora, en 1944, en el marco de esa aproximación ontológica al cristianismo, Zubiri recurre no solo a los escritos paulinos, y no solo a lo que llama, en términos muy generales, "teología griega", y no solo a la teología latina que sirve a sus intereses ontológicos, y no solo a la teología contemporánea que puede ser integrada dentro de su perspectiva, sino también a la teología de Odo Casel, aunque sin nombrarlo explícitamente ${ }^{94}$.

La razón es la siguiente: según Zubiri, Casel va un paso más allá de los griegos en la conceptuación de los sacramentos. Como Zubiri ya decía en el curso "Helenismo y cristianismo", la doctrina católica sostenía que los sacramentos son acciones de Cristo que producen en el creyente aquello que significa; pero -como Zubiri señala en 1944- esa doctrina oficial por lo general deja abierta la índole concreta de esa producción; y entonces tenemos que considerar las distintas teorías con las que Zubiri se encuentra en su contexto.

1. Tenemos la teoría llamada de la "causalidad moral", según la cual los sacramentos hacen que los fieles tengan "el mismo modo de sentir que tuvo Jesucristo". 95 Es la doctrina usualmente defendida por los nominalistas, por Melchor Cano o Francisco Suárez. ${ }^{96}$ En 1944, Zubiri la consideraba minoritaria y, de acuerdo a sus intereses ontológicos, le parecía insuficiente. Según Zubiri, habría que señalar que además de una producción moral hay una producción física y real. ${ }^{97}$

2. En segundo lugar, se puede hablar, en términos muy generales, de una teoría de la "causalidad física", según la cual los sacramentos producen una unión real y física con Cristo. De hecho, se puede decir que esta teoría es la que usualmente caracteriza las posiciones católicas sobre los sacramentos. A veces, esta teoría se remite a Tomás de Aquino, quien sostiene que los sacramentos producen un efecto real en el alma de quien los recibe, y esta efectividad real diferencia los sacramentos cristianos del carácter meramente signitivo de los ritos del Antiguo Testamento. ${ }^{98}$

Sin embargo, en la Summa, Tomás no precisa el carácter concreto de la causalidad sacramental, e incluso se ha discutido sobre si hay, en este punto, una evolución

\footnotetext{
${ }^{94}$ Como G.uillermina Díaz ha mostrado en su mencionado estudio.

${ }^{95}$ Flp 2,5, citado en Naturaleza, historia, Dios, 461. Es significativo que Zubiri solamente cite a Pablo respecto a la causalidad moral.

${ }^{96}$ Zubiri, El problema teologal del hombre, 347.

${ }^{97}$ Idem, Naturaleza, historia, Dios, 461.

${ }^{98}$ Ver a Tomás de Aquino, Summa theologiae III, q. 62.
} 
en su pensamiento. En cualquier caso, Zubiri no se refiere a Tomás, sino que asume en términos generales la tesis de una efectividad física de los sacramentos, pero entiende que hay que precisar más la índole de esta causalidad.

3. En este punto, como no puede ser menos, Zubiri recurre a la "causalidad formal”, según la cual acontece una irradiación formal de la causa en el efecto. Según Zubiri, "en esta irradiación se halla para los griegos lo propio de la causalidad". 99 Como Zubiri ha venido subrayando a lo largo del trabajo, la causalidad formal admite distintos modos. En el caso de los sacramentos, esto significa que, desde la perspectiva de los griegos, las acciones sacramentales "han de ser entendidas desde el punto de vista de la participación real del hombre en la redención de Cristo, participación que se produce en aquellas acciones". ${ }^{100}$

En este punto estaría precisamente la diferencia con un punto de vista centrado únicamente en la eficiencia de la causa sobre el efecto. En la concepción usual de la causalidad física, la redención ha tenido lugar en el tiempo, y sirve como causa eficiente y meritoria que solo se perpetúa en sus efectos. En cambio, desde el punto de vista griego, la causalidad física tiene un carácter formal, de modo que la causa tiene realidad actual en el efecto, "si bien que en su contenido y en un modo puramente de misterio". ${ }^{101}$

Los sacramentos serían entonces una participación real en el acto de la redención, del que reciben su valor y su eficacia. Por eso se puede decir que "en una u otra forma" el sacramento reproduce lo sucedido en el Calvario, y que la obra de Cristo se encuentra entonces presente "en algún modo" en los que reciben el sacramento. ${ }^{102}$

4. Hasta aquí tendríamos la posición de los griegos. Sin embargo, cabría según Zubiri dar un paso más. Es donde Zubiri expone la posición de Casel. Lo propio de Casel sería, según Zubiri, haber precisado el modo de la presencia de la obra de Cristo “en los que reciben el sacramento". Lo que estaría presente -según Casel- sería "el sacrificio redentor en todo el decurso de su integridad". ${ }^{103}$

Tendríamos entonces dos modos de presencia de Cristo: por un lado, el modo histórico, y por otro, el modo "místico", que no sería menos real. ${ }^{104} \mathrm{La}$ obra redentora

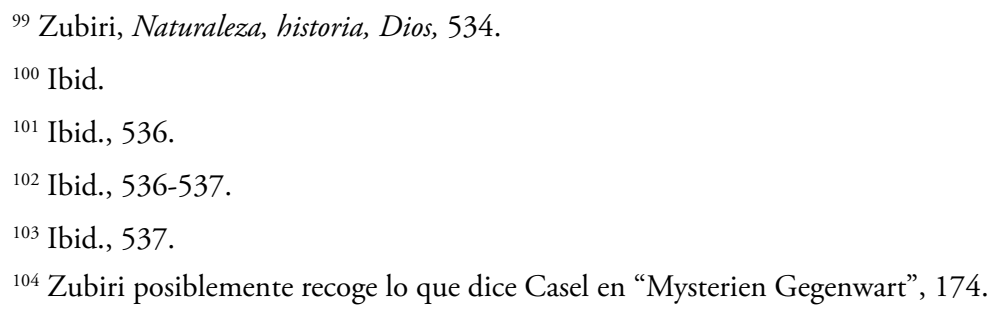


de Cristo estaría presente "por vía de causalidad formal y ejemplar" ${ }^{105}$ Zubiri indica aquí cuál es la diferencia con los padres griegos. Estos hablan de una participación de los creyentes en la obra redentora de Cristo, mientras que Casel señala que esa obra se halla presente, por ejemplaridad, en todo su despliegue, en el efecto sacramental.

Ahora bien, Zubiri señala que estas dos teorías no están en contradicción, sino que la teoría de Casel puede ser considerada como una especie de conclusión lógica a la que converge asintóticamente la teoría de los griegos, habiendo entre ambas teorías una distancia solamente "milimétrica". ${ }^{106}$

Es interesante que Zubiri señale la existencia de una distancia, aunque sea milimétrica, entre la tesis patrística y la propia de la teología de los misterios, porque precisamente esa distancia es la que trató de negar el propio Odo Casel cuando repetidamente adujo el testimonio de los padres griegos en defensa de su propia teoría. ${ }^{107}$ En este punto, Zubiri está más cerca de Schmaus, quien en las distintas ediciones de su obra sostuvo la existencia de una diferencia entre la posición de Casel y la propia de los padres griegos. ${ }^{108}$

Esta pequeña distancia milimétrica entre los padres griegos y la teología de los misterios es también importante por otra razón, relativa a la interpretación de Pablo. Odo Casel insistió en que su interpretación de los misterios se podía remitir en último término al Capítulo 6 de la Carta a los Romanos, especialmente al versículo 5, donde habla de una "semejanza" (homoioma) con la muerte de Cristo.

A partir de la segunda mitad del siglo XX, la mayor parte de los exegetas, tanto católicos como protestantes, entienden que el texto habla claramente de que en el bautismo acontecería una verdadera participación en la muerte de Cristo. En cambio, difícilmente estarían dispuestos a admitir que en el bautismo la muerte de Cristo acontezca de nuevo en el creyente, aunque sea in mysterio. ${ }^{109}$ No deja de ser interesante señalar que Warnach moderó mucho las pretensiones de su maestro Casel respecto de

\footnotetext{
${ }^{105}$ Zubiri, Naturaleza, historia, Dios, 537.

${ }^{106}$ Ibid.

${ }^{107}$ Casel, "Neue Zeugnisse für das Kultmysterium”, en Jahrbuch für Liturgiewissenschaft 13 (1933): 111-113.

${ }^{108}$ Schmaus, Katholische Dogmatik, IV/1, 55. En la edición de 1956 Schmaus llegó a señalar que "la teología de los misterios identifica demasiado pronto y sin la dirección crítica necesaria la doctrina patrística del carácter conmemorativo de los sacramentos con su teoría de la actualización de la muerte de Cristo en los sacramentos". citado según la traducción castellana: Schmaus, Teología dogmática, Vol. 6, 75.

${ }^{109}$ Schnackenburg, Baptism in the Thought of St. Paul: A Study in Pauline Theology, 132; Ridderbos, Paul: An Outline of His Theology, 407-408.
} 
la interpretación de este texto paulino, reconociendo que Pablo no resuelve plenamente el modo en el que se ha de entender la presencia cúltica de Cristo. ${ }^{110}$

El problema es grave y requiere de precisión conceptual. Aquí es relevante observar que Zubiri, quien en algún modo parece simpatizar con la teoría de Casel, señala que en la teoría de Casel no solo se utiliza una causalidad formal, sino también a una causalidad ejemplar. ${ }^{11}$ La diferencia es importante porque, como Schmaus bien advierte, la teología de Casel implica una interpretación de los padres griegos desde el punto de vista de la filosofía platónica. ${ }^{112}$ Frente a esa interpretación la única alternativa posible no es, como piensa Schmaus, la mera causalidad eficiente.

Lo que Zubiri ha hecho es interpretar los padres griegos, no desde el platonismo, sino desde el aristotelismo; pero en el aristotelismo no solo hay causas eficientes, sino también causas formales. En el caso de los sacramentos, la causalidad formal no excluye la eficiencia, pero esta eficiencia solo sirve de vehículo para una irradiación de la causa formal sobre el efecto. ${ }^{113}$

Esto, por supuesto, también lo afirma Casel, pero añade una causalidad ejemplar y no solo formal. En la causalidad ejemplar, la imagen ideal está enteramente presente en sus efectos, que la imitan "en todo su despliegue" o "en todo el decurso de su integridad", como dice Zubiri. ${ }^{114}$ En cambio, la causalidad formal implica algún tipo de irradiación de la causa sobre el efecto, pero no exige que la causa esté presente en todo su despliegue sobre el efecto.

En definitiva, la forma aristotélica es siempre un momento individual de la realidad, y esta individualidad será precisamente algo que también el propio Zubiri subrayará en su filosofía madura. Respecto del sacramento, la causalidad formal implica algún tipo de irradiación de la causa (obra redentora de Cristo) sobre el efecto (los que reciben el efecto), pero no implica necesariamente una reproducción de la causa "en todo su despliegue".

Todo ello no obsta para que Zubiri valore positivamente el intento de Casel. También es importante señalar que, ya en 1944, Zubiri quiere ir más allá de Casel, sugiriendo otro enfoque de la cuestión sacramental. Para ello, no recurre a teorías

\footnotetext{
${ }^{110}$ Warnach, "Taufe und Christusgeschehen nach Römer 6”, 329ss.

${ }^{111}$ Zubiri, Naturaleza, historia, Dios, 537.

${ }^{112}$ Schmaus, Teología dogmática, Vo.l. 6, 74-75.

${ }^{113}$ Zubiri, Naturaleza, historia, Dios, 534.

${ }^{114}$ Ibid., 537.
} 
vinculadas a la teología de los misterios, como la de Gottlieb Söhngen, quien propuso entender los sacramentos, no desde la presencia de la obra redentora en su integridad, sino más bien desde la presencia del Cristo que hoy vive, y que sigue portando en sí mismo los efectos de su pasión. Estos efectos serían los que se hacen presentes en quienes reciben los sacramentos. ${ }^{115}$ Con esto, Söhngen pretendía evitar la alternativa entre una participación del creyente actual en una acción ya pasada, y la actualización de esa obra en el presente.

Zubiri tampoco recurre a Warnach, quien esbozó una solución semejante, sugiriendo que el misterio de la salvación está situado en un "hoy" intemporal, al que nos incorporamos mediante el sacramento. ${ }^{116} \mathrm{En}$ "El ser sobrenatural", la perspectiva es distinta. Zubiri, en una nota ${ }^{117}$, recurre al representante de otra teoría sacramental, a quien ya encontramos explícitamente citado en el curso "Helenismo y cristianismo". Se trata del cardenal Louis Billot. ${ }^{118}$

5. La teoría de Billot sobre los sacramentos trata de entenderlos en virtud de una "causalidad intencional", distinta de la causalidad física en sentido usual y distinta de la causalidad moral.

La teoría de la causalidad intencional tendría su origen en algunos autores medievales ${ }^{119}$, para quienes los sacramentos no obrarían de modo perfectivo (perfective), sino solo de modo dispositivo (dispositive), preparando al que los recibe para la obra de la gracia, que sería ejecutada directamente por Dios. Los autores medievales tenderían a pensar que esa predisposición para la gracia es una predisposición física. ${ }^{120}$

En cambio, Billot, al partir de ellos, y apelar a su propia interpretación de Tomás de Aquino, solo reconoce una predisposición intencional. Los sacramentos operan la gracia intentionaliter dispositive, proporcionando un título exigitivo para la gracia, en el sentido de un derecho a la misma. La consecuencia de este derecho sería la donación infalible de la gracia por parte de Dios. De este modo, el aspecto

\footnotetext{
${ }^{115}$ Ver a Söhngen, Der Wesensaufbau des Mysteriums.

116 Warnach, "Zum Problem der Mysteriengegenwart", 9-39.

117 Zubiri, Naturaleza, historia, Dios, 537-538.

${ }^{118}$ Billot renunció (o fue obligado a renunciar) al cardenalato debido a su oposición a la condena de Pío XI de la Action Française, un movimiento político extremadamente conservador. Billot entendía su teoría de los sacramentos como una exposición de la posición tomista.

${ }^{119}$ Tal vez el primero de ellos fuera el mismo Alejandro de Hales, a quien Zubiri cita repetidamente en su trabajo. Ver Zubiri, Naturaleza, historia, Dios, 458, 465, 473, 492.

${ }^{120}$ Billot, De ecclesiae sacramentis. Comentarius in tertiam partem S. Thomae, 76 y ss.
} 
eficiente de la gracia estaría siempre subordinado al signitivo o intencional, que sería el propio de los sacramentos. ${ }^{121}$

Zubiri, en la nota mencionada, señala que "la relación intencional, sobre todo cuando es eficaz, es de tipo más bien formal"; sugiere entonces que "la teoría de Billot, desarrollada en esta dirección, mostraría una fecundidad insospechada" ${ }^{122}$ Esta fecundidad, que Zubiri no explica, consistiría posiblemente en que la teoría de Billot quedaría abierta a admitir una reproducción real de la obra redentora en quien recibe los sacramentos, aunque esa reproducción no tendría que entenderse como efecto del sacramento, sino más bien como obra directa de Dios mismo en el creyente.

De este modo, se evitaría la alternativa entre una actualización en el presente de la obra redentora ya pasada y la participación actual en una obra del pasado. Lo que se actualizaría sería la gracia de Dios, que en definitiva, en el planteamiento de Zubiri, no es sino Dios mismo. Sin embargo, esa actualización tendría lugar de acuerdo con la eficacia formal del sacramento, que estaría intencionalmente referida a la obra de Cristo, al mismo tiempo que nos dispondría para la recepción de la gracia, o nos daría incluso un título exigitivo a la misma, de acuerdo con la libre determinación de Dios al establecer los sacramentos.

En cualquier caso, no deja de ser significativo que la teoría de Billot parta de reflexiones medievales sobre dos tipos de causalidad, dispositiva y exigitiva, que después Zubiri utilizará profusamente en su filosofía madura para tratar muy diversos temas, mucho más allá de la teología sacramental.

Lo decisivo, para nuestra pregunta, es caer en cuenta que los distintos autores considerados, tanto Casel como Billot, o el mismo Schmaus, son utilizados de manera crítica por Zubiri, para ser integrados en una perspectiva más amplia, que consiste en su interpretación del cristianismo en términos de deificación, la cual se originó, como vimos, en diálogo con la teología contemporánea y, sobre todo, aprovechando los impulsos ontológicos recibidos de Heidegger.

Las distintas teologías son incorporadas por Zubiri a esa interpretación del cristianismo, a su vez solidaria de una cierta lectura de Aristóteles, que tiene como ejes principales la afirmación del carácter esencialmente activo del ser de Dios, y el concepto de causalidad formal. $\mathrm{Y}$ entonces podemos preguntarnos si lo que tenemos en

${ }^{121}$ Ibid., especialmente 53 y ss. Zubiri contaba en su biblioteca personal con varias obras de Billot. Es significativo que el libro de Billot sobre los sacramentos estuviera entre las obras que Zubiri mantenía a la mano, cerca de su mesa de trabajo, y que esté repetidamente señalado y subrayado.

${ }^{122}$ Zubiri, Naturaleza, historia, Dios, 538n. 
el texto de 1944 son verdaderamente unas "simples páginas históricas", como Zubiri afirma al principio de las mismas. ${ }^{123}$

\section{Perspectivas}

No se puede negar la evidente simpatía de Zubiri por las posiciones expuestas; tampoco que esas posiciones teológicas son enmarcadas en una perspectiva ontológica enormemente coherente, que conforma una interpretación unitaria del cristianismo. En este sentido, las páginas no son meramente históricas en el sentido usual de lo que puede ser la historiografía teológica o filosófica.

Sin embargo, también hay que señalar que la "teología filosófica" u "ontología teológica" que Zubiri expone en el trabajo "El ser sobrenatural" no representa plenamente su propia posición intelectual, ni siquiera en los años cuarenta. Esto, por varias razones:

- $\quad$ En primer lugar, si Zubiri hubiera querido exponer su propia posición teológica en 1944, es difícil pensar que se hubiera limitado a poner de manifiesto la posibilidad de leer la teología paulina y la patrística griega, desde el punto de vista de una interpretación activista de la ontología de Aristóteles. Zubiri, para exponer su propia teología, hubiera tenido en cuenta sus propios conocimientos sobre la mentalidad semítica, que ya había puesto de relieve en el curso "Helenismo y cristianismo" o en los trabajos "Sobre el problema de la teología”. Estos conocimientos de la mentalidad semítica fueron utilizados por Zubiri repetidamente en sus obras filosóficas más importantes, y sería extraño que no se hubieran hecho presentes en un trabajo teológico. - En segundo lugar, aunque en 1944 Zubiri no tenía todavía una filosofía madura, sí había ido apropiándose y desarrollando algunos conceptos filosóficos que mantendría a lo largo de su evolución intelectual. Algunos de estos conceptos filosóficos son perfectamente aplicables a los problemas teológicos, y de hecho Zubiri ya había comenzado esta aplicación antes de 1944. Así, por ejemplo, en el trabajo de 1935, "En torno al problema de Dios", Zubiri proponía interpretar el pecado original utilizando la diferencia entre el concepto aristotélico de potencia y el concepto, tomado de Heidegger, de posibilidad. ${ }^{124}$

Se trata de una distinción clave, que establece una diferencia con Aristóteles y que permitió al Zubiri de aquellos años la elaboración un esbozo de filosofía de la historia, entendida como apropiación de posibilidades. ${ }^{125} \mathrm{Y}$ no olvidemos que la

\footnotetext{
${ }^{123}$ Ibid., 456.

${ }^{124}$ Ibid., 451.

${ }^{125}$ Ibid., 362-383.
} 
historia es un concepto central para el pensamiento hebreo, insatisfactoriamente integrado en la metafísica aristotélica, de la que Zubiri se distancia de este modo. En cualquier caso, Zubiri no aprovecha su propio concepto de historia para la exposición del pecado, sino permanece en las categorías más cósmicas del pensamiento griego, para el que el pecado es una mácula en la creación.

- $\quad$ En tercer lugar, hay un punto todavía más decisivo en la evolución intelectual de Zubiri. Ya a comienzos de los años 30, había señalado la necesidad de ir más allá del ser. ${ }^{126}$ La distinción entre realidad y ser, aunque no está desarrollada sistemáticamente, ya asoma en las páginas de Naturaleza, historia, Dios. ${ }^{127}$

Pues bien, en el ya mencionado trabajo del año 1935, Zubiri señalaba que Dios está más allá del ser. Es una distinción que se mantendrá en la filosofía madura de Zubiri: si el ser es la actualidad ulterior de lo real en el mundo, la realidad de Dios no tiene propiamente ser. En el año 1935, Zubiri apela a distintos místicos y teólogos para sostener que Dios está más allá del ser: el maestro Ekhardt, Mario Victorino, Juan Escoto Eriúgena, Cayetano, o el mismo Tomás. ${ }^{128}$ Son autores que no aparecen integrados en el trabajo del año 1944 sobre "El ser sobrenatural", precisamente porque se encuentran en una posición extraña a la ontología que Zubiri atribuye a los padres griegos.

En 1944, Zubiri es consciente perfectamente de la necesidad de distinguir entre realidad y ser. Y, sin embargo, su exposición de la teología griega se hace al margen de esa distinción, simplemente mostrando que los padres griegos tuvieron un concepto activo del ser, derivado de su interpretación de Aristóteles. ${ }^{129} \mathrm{Ni}$ qué decir tiene que Zubiri, de haber expuesto su propia posición respecto a la realidad de Dios, hubiera procedido de otra manera.

- En cuarto lugar, el mismo planteamiento ontológico de los padres griegos tiene algunas dificultades desde el punto de vista del pensamiento de Zubiri, tal como se está configurando en esos años. Así, por ejemplo, Zubiri ha destacado que los padres griegos parten del ser efusivo de Dios, lo cual puede converger con el interés de Zubiri en evitar un punto de partida en la presunta nihilidad creatural de las cosas, al estilo de Agustín.

${ }^{126}$ Ibid., 286-287.

${ }^{127}$ Ibid., 124.

${ }^{128}$ Ibid., 441-442.

${ }^{129}$ Ibid., 465ss. 
Sin embargo, Zubiri entiende que el horizonte de la nihilidad se ha de superar mediante una filosofía que parta de sí misma, en inmediato contacto con las cosas. ${ }^{130}$ Es lo que llamará posteriormente una "metafísica intramundana". ${ }^{131} Y$ no es esto lo que se encuentra en los padres griegos, precisamente porque parten del ser efusivo de Dios.

Zubiri señala críticamente que los padres griegos no distinguieron entre esa ontología sobrenatural y lo que se podría llamar una ontología racional del ser finito, es decir, una ontología de base puramente filosófica, y no teológica. Para los padres griegos, la ontología racional no sería más que "la ontología usual de Dios en sus producciones ad extra" ${ }^{132} \mathrm{Y}$ esto significa que, para Zubiri, la ontología aristotélica y activista expuesta por él mismo como la ontología presupuesta por los padres griegos no cumple los requisitos propios de una filosofía que parta de sí misma, sino que es una ontología que parte del dato revelado, que no es otro que la revelación de Dios como amor. Por eso Zubiri tiene que decir que son páginas históricas: ellas constituyen su interpretación ontológica de los padres griegos, pero no su propia filosofía, y por ende tampoco su propia teología.

- También cabría considerar, en quinto lugar, que la misma interpretación "activista" de Aristóteles, por más que esté expuesta magistralmente por Zubiri, no se puede atribuir tan fácilmente a Zubiri mismo. Que Zubiri la considere como la ontología propia de la patrística griega es una cosa, y otra que Zubiri la haga suya. La interpretación que Zubiri hace de Aristóteles, tanto en los años 30 y 40 como en su filosofía madura, no parece ser precisamente la que encontramos en el texto de 1944 sobre los padres griegos.

Además, habría que decir que la propia evolución de Zubiri le hará ir tomando distancia respecto de las teologías incorporadas a su trabajo de 1944. Sobre Billot, Zubiri hizo críticas más bien ásperas. ${ }^{133}$ Otras teologías, pese a su pujanza en los años 30, experimentaron un cierto apagamiento después de la segunda Guerra Mundial. Así, por ejemplo, la teología de los misterios no solo tuvo que asumir la dificultad de vincular el concepto paulino de misterio con los sacramentos. Su interpetación del cristianismo tendía a subrayar la conexión con el mundo helénico, y pudo incluso despertar simpatías en la época del nacional-socialismo. ${ }^{134}$ Sin embargo, después de la

\footnotetext{
${ }^{130}$ Idem, Sobre el problema de la filosofía y otros escritos (1932-1944), 123-124.

${ }^{131}$ Idem, Acerca del mundo, 88; Idem, Sobre la esencia, 201, 210, 237, 303.

${ }^{132}$ Idem, Naturaleza, historia, Dios, 528.

${ }^{133}$ Idem, El problema teologal del hombre, 393.

${ }^{134}$ Albert, Die Benediktinerabtei Maria Laach und der Nationalsozialismus, 163-164.
} 
Segunda Guerra Mundial la teología comenzó a caer en la cuenta de las propias raíces judías, incluyendo las raíces judías del pensamiento de Pablo.

Por otra parte, los trabajos de Hugo Rahner mostraron que la práctica y la terminología ligada a los misterios es relativamente tardía en el cristianismo, pues solo se popularizó cuando se hizo necesario desarrollar programas de iniciación para hacer frente a la incorporación masiva de los paganos a las iglesias. ${ }^{135}$

En sus obras posteriores de contenido teológico, Zubiri se distanció de la terminología "mistérica" 136 , y emprendió un enfoque distinto de la teología sacramental. En la obra madura de Zubiri, los sacramentos son entendidos primeramente como acciones ${ }^{137}$, y no como realidad mistérica, invirtiendo así las posiciones de la teología de los misterios recogidas en el trabajo de $1944 .{ }^{138}$

Lo más relevante, en este punto, es que Zubiri abandona completamente la terminología causal. La eficacia de los sacramentos no es, para Zubiri, una cuestión de causalidad: ni causalidad moral, ni eficiente, ni instrumental, ni formal, ni ejemplar, ni dispositiva, ni exigitiva. En la obra madura de Zubiri, los sacramentos pasarán a ser pensados en términos de dominancia. ${ }^{139}$ Algo que es perfectamente comprensible desde la propia evolución de las categorías filosóficas de Zubiri, y su reflexión sobre el poder de lo real.

Es cierto que la filosofía de Zubiri, tanto en los años 30 como en su madurez, se diferencia en puntos decisivos de la ontología expuesta en su trabajo teológico de 1944. También es cierto que en su madurez, él se interesó por otras teologías, como la de Karl Rahner, entre otras. A pesar de ello, tanto el curso "Helenismo y cristianismo" como el escrito "El ser sobrenatural" nos proporcionan algunas claves decisivas sobre la génesis y evolución del pensamiento teológico de Zubiri.

Su lectura "ontológica" del cristianismo (aunque desde la perspectiva de la última filosofía de Zubiri habría que decir "metafísica") se mantendrá hasta el final, de modo que el término de "deiformación” se convertirá en la clave definitiva de su

\footnotetext{
${ }^{135}$ H. Rahner, Griechische Mythen in christlicher Deutung, 65-66.

136 Zubiri, El problema teologal del hombre, 192.

${ }^{137}$ Ibid., 313 y ss. A partir de las acciones se desplegaría la diferencia entre realidad y ser, propia del pensamiento maduro de Zubiri.

${ }^{138}$ Idem, Naturaleza, historia, Dios, 530. La acción se remitía a realidad mistérica.

${ }^{139}$ El cambio de posición ya se anuncia en Acerca del mundo, 23, donde se sustituye la causalidad física por una causalidad real, entendida en términos de poder. Más adelante, Zubiri negará que los sacramentos se puedan entender en términos de causalidad, y propondrá una comprensión desde el concepto de dominancia. Ver a Zubiri, El problema teologal del hombre, 347-348.
} 
reflexión teológica. No se trata de pensar que los autores utilizados en los años 30 y 40 configuraron todo su pensamiento teológico. Se trata más bien de haber constatado algunas líneas de fondo que explican precisamente el hecho de que Zubiri se interesara en los años 30 y 40 por ciertos autores, y que ulteriormente se volviera hacia otros.

Como filósofo, Zubiri trató de entender el cristianismo primitivo (en principio los escritos paulinos), y el cristianismo en general, desde su dimensión ontológica o metafísica. Y este enfoque fundamental fue determinante, a lo largo de toda su evolución intelectual, para que Zubiri pudiera acercarse a determinadas teologías, a las que siempre utilizó de una manera libre y crítica, dentro de su propio proyecto. El entusiasmo por Zubiri por unas y otros no fue siempre el mismo, pero siempre se mantuvo dentro de la perspectiva mencionada, y que podemos designar, resumidamente, como la perspectiva de la deiformación.

Esta perspectiva es precisamente la que nos permite entender y situar, en su evolución intelectual, la relevancia, mayor o menor, de pensamientos tan variados como los de Schleiermacher y Heidegger, Von Soden y Stolz, Aristóteles y Tillich, los padres griegos y los teólogos victorinos, Schmaus y Casel, Lagrange y Billot, De Lubac, Rahner, etc. Todos ellos, críticamente leídos, tienen su lugar en la trayectoria intelectual y en el diálogo vivo de un autor que, precisamente por la amplitud de sus miras filosóficas y teológicas, no puede ser reducido a ninguno de ellos.

\section{Bibliografía}

Albert, Marcel. Die Benediktinerabtei Maria Laach und der Nationalsozialismus. Paderborn: Ferdinand Schöningh Verlag, 2004.

Barth, Karl. Protestant Thought: From Rousseau to Ritschl. New York: Harper \& Brothers, 1959.

Baur, F. Ch. Paulus. Der Apostel Jesu Christi. Stuttgart: Becher und Müller, 1845.

Billot, Ludovico. De ecclesiae sacramentis commentarius in tertiam partem S. Thomae (7a. ed.). Roma: Pontificia Università Gregoriana, 1931. . De personali et originali peccato. Prati: Giachetti, Filii, 1910.

Bossuet, W. Das Wesen Der Religion Dargestellt an Ihrer Geschichte. Tübingen: s/e, 1920 [1 1 a ed. 1904].

. Kyrios Christos. Geschichte des Christus-Glauben von den Anfängen des Christentums bis Irenäus. Göttingen: Vandenhoeck und Ruprech, 1913.

Bultmann, Rudolf. "Neues Testament und Mythologie." En Kerygma und Mythos, editado por H.W. Bartsch, Vol. 1, 15-48. Hamburg: Herbert Reich, 1951. 
. "Zum Problem der Entmythologisierung." En Kerygma und Mythos, editado por H.W. Bartsch, Vol. 2, 177-208. Hamburg: Herbert Reich, 1952.

. "Zum Problem der Entmythologisierung." En Kerygma und Mythos, editado por H.W. Bartsch, Vol. 4-1, 20-27. Hamburg: Herbert Reich, 1963.

Casel, S. “Mysterien gegenwart.” Jahrbuch für Liturgiewissenschaft 8 (1928): 145-224. . "Neue Zeugnisse für das Kultmysterium." Jahrbuch für Liturgiewissenschaft 13 (1933): 111-113.

Corominas, J. y J. A. Vicens. Xavier Zubiri. La soledad sonora. Madrid: Taurus, 2006.

De Lubac, Henri. "Causes internes de l'atténuation et de la disparition du sens du Sacré." En Théologie dans l'histoire: II Questions disputées et résistance au nazisme, por H. de Lubac, 13-30. Paris: Desclée de Brouwer, 1990.

. Surnaturel. Paris: Aubier, 1946.

Denzinger, H. y A. Schönmetzer. Enchiridion symbolorum, definitionum et declarationum de rebus fidei et morum. Barcelona: Herder, 1976.

Díaz Muñoz, Guillermina. Teologia del misterio en Zubiri. Barcelona: Herder, 2008.

Domínguez, Emilio José Justo. "La deificación en el pensamiento de Xavier Zubiri." Tesis de Licenciatura, Universidad Pontificia de Salamanca, Facultad de Teología, 2002.

González, Antonio. "El eslabón aristotélico." Cuadernos salmantinos de filosofía 35 (2008): 5-36.

Heidegger, M. Phänomenologie des religiösen Lebens. Frankfurt a. M.: Klostermann, 1995.

Küng, Hans. Grandes pensadores cristianos. Madrid: Trotta, 1995.

Lagrange, M.-J. Le sens du christianisme d'après l'exégèse allemande. Paris: J. Gabalda, 1918.

Luther, Martin. D. Martin Luthers Werke: Kritische Gesamtausgabe. Vol. 13. Weimar: Hermann Böhlaus Nachfolger, 1883-1929.

Meyer, Arthur. Die Auferstehung Christi: Die Berichte über Auferstehung, Himmelfahrt und Pfingsten, ihre Entstehung, ihr geschichtlicher Hintergrund, und ihre religiöse Bedeutung. Tübingen: Mohr, 1905.

Otto, Rudolf. Das Heilige. München: Beck, 1932. 
Rahner, Hugo. Griechische Mythen in christlicher Deutung (2a. ed.). Zurich: Rhein Vlg., 1957.

Rahner, Karl. "Der dreifaltige Gott als transzendenter Urgrund der Heilsgeshichte." En Mysterium salutis, editado por J. Feiner y M. Löhrer, Vol. 2, 317-401. Zürich: Benzinger, 1978.

Régnon, Th. De. Études de théologie positive sur la Sainte Trinité. 4 vols. Paris: Victor Retaux 1892-1898.

Ricardo de San Víctor. De Trinitate. Paris: Du Cerf, 1959.

Ridderbos, H. Paul: An Outline of His Theology. London: SPCK, 1975.

Schleiermacher, Friedrich. Der christliche Glaube. 2. Aufgabe (1830-1831). Editado por Rolf Schäfer. Berlin-New York: Walter de Gruyter, 2003.

Schmaus, Michael. Katholische Dogmatik. Die Lehre von den Sakramenten. Vol IV/1. Munich: Max Hueber Verlag, 1952.

. Teología dogmática. Vol. VI. Los sacramentos. Madrid: Rialp, 1961.

Schnackenburg, Rudolf. Baptism in the Thought of St. Paul: A Study in Pauline Theology. Oxford: Basil Blackwell, 1964.

Söhngen, Gottlieb. Der Wesensaufbau des Mysteriums. Bonn: P. Hanstein, 1938.

Stolz, Anselm. De Sanctissima Trinitate. Freburg: Herder, 1939.

Tomás de Aquino. Summa theologiae. Opera Omnia. Roma: Editio Leonina, 18881906.

Von Soden, H. Was ist Wahrheit? Vom geschichtlichen Begriff der Wahrheit. Marburg: Marburger Akademische Reden, 1927.

Warnach, Viktor. "Taufe und Christusgeschehen nach Römer 6." Archiv für Liturgiewissenschaft Vol. III/2 (1954): 284-366.

. “Zum Problem der Mysteriengegenwart.” Liturgisches Leben 5 (1938): 9-39.

Weiss, J. Die Predigt Jesu vom Reiche Gottes. Göttingen: Vanderhoeck und Ruprecht, 1892.

Zubiri, Xavier. Acerca del mundo. Edición a cargo de Antonio González. Madrid: Alianza Editorial, 2010.

. Cinco lecciones de filosofía. Madrid: Alianza Editorial, 1997 [1a. ed.: Madrid: Sociedad de Estudios y Publicaciones, 1963]. 
. Cinco lecciones de filosofía. Con un nuevo curso inédito. Edición a cargo de Antonio Pintor Ramos. Madrid: Alianza Editorial, 2009.

. Cursos universitarios. Vol. 1. Edición a cargo de a cargo de Manuel Mazón. Madrid: Alianza Editorial, 2007.

. Cursos universitarios. Vol. 2. Edición a cargo de a cargo de Manuel Mazón. Madrid: Alianza Editorial, 2010.

. Cursos universitarios. Vol. 3. Edición a cargo de a cargo de Manuel Mazón. Madrid: Alianza Editorial, 2012.

. El hombre: lo real y lo irreal. Edición a cargo de Jesús Conill. Madrid: Alianza Editorial-Fundación Xavier Zubiri, 2005.

. El hombre y Dios (2a. ed.). Madrid: Alianza Editorial-Sociedad de Estudios y Publicaciones, 1985 [1ª ed. a cargo de Ignacio Ellacuría, 1984].

. El hombre y la verdad. Edición a cargo de Juan Antonio Nicolás. Madrid: Alianza Editorial-Fundación Xavier Zubiri, 1999.

- El problema filosófico de la historia de las religiones. Edición a cargo de Antonio González. Madrid: Alianza Editorial-Fundación Xavier Zubiri, 1993.

. El problema teologal del hombre: cristianismo. Edición a cargo de Antonio González. Madrid: Alianza Editorial-Fundación Xavier Zubiri, 1997.

. "En memoria del P. Lagrange O.P., doctor de la tradición bíblica." En Sobre el problema de la filosofía y otros escritos (1932-1944), editado por Germán Marquínez Argote, 285 y ss. Madrid: Alianza Editorial-Fundación Xavier Zubiri, 2002.

. "En torno al problema de Dios." En Naturaleza, historia, Dios, por X. Zubiri, 417-454. Madrid: Alianza Editorial-Fundación Xavier Zubiri, Madrid, 1987.

. Escritos menores (1953-1983). Edición a cargo de Germán Marquínez Argote. Madrid: Alianza Editorial-Fundación Xavier Zubiri, 2007.

. Espacio. Tiempo. Materia. Edición preparada por Antonio Ferraz. Madrid: Alianza Editorial-Fundación Xavier Zubiri, 1996 [2a. ed. revisada: 2008].

. Estructura dinámica de la realidad. Edición a cargo de Diego García. Madrid: Alianza Editorial, 1989.

. Inteligencia y logos. Madrid: Alianza Editorial-Sociedad de Estudios y Publicaciones, 1982. 
. Inteligencia y razón. Madrid: Alianza Editorial-Sociedad de Estudios y Publicaciones, 1983.

. Inteligencia sentiente. Inteligencia y realidad. Madrid: Alianza Editorial-Sociedad de Estudios y Publicaciones 1980.

. Los problemas fundamentales de la metafísica occidental. Edición a cargo de Antonio Pintor ramos. Madrid: Alianza Editorial-Fundación Xavier Zubiri, 1994. . Naturaleza, historia, Dios. Madrid: Alianza Editorial-Fundación Xavier Zubiri, Madrid, 1987 [1a. ed.: Madrid: Editora Nacional, 1944.]

- Primeros escritos (1921-1926). Edición a cargo de Antonio Pintor Ramos. Madrid: Alianza Editorial-Fundación Xavier Zubiri, 2000.

. Sobre el hombre. Madrid: Alianza Editorial-Fundación Xavier Zubiri, 1998 [ $1^{\text {a }}$ ed a cargo de Ignacio Ellacuría. Madrid: Alianza Editorial-Sociedad de Estudios y Publicaciones, 1986].

. Sobre el problema de la filosofía. Fascículo. Madrid: Fundación Xavier Zubiri, 1996.

. Sobre el problema de la filosofía y otros escritos (1932-1944). Edición a cargo de Germán Marquínez Argote. Madrid: Alianza Editorial-Fundación Xavier Zubiri, 2002.

. Sobre el sentimiento y la volición. Presentación por Diego García. Madrid: Alianza Editorial-Fundación Xavier Zubiri, 1992.

. Sobre la esencia. Madrid: Alianza Editorial-Fundación Xavier Zubiri, 1998 [1a. ed.: Sociedad de Estudios y Publicaciones, 1962].

. Sobre la realidad. Edición a cargo de José Antonio Martínez. Madrid: Alianza Editorial-Fundación Xavier Zubiri, 2001.

. Tres dimensiones del hombre: individual, social e histórica. Edición a cargo de Jordi Corominas. Madrid: Alianza Editorial-Fundación Xavier Zubiri, 2006. 